\title{
Crystal Chemistry and Structural Complexity of the Uranyl Carbonate Minerals and Synthetic Compounds
}

\author{
Vladislav V. Gurzhiy ${ }^{1, * \mathbb{D}}$, Sophia A. Kalashnikova ${ }^{1}$, Ivan V. Kuporev ${ }^{1} \mathbb{D}$ and Jakub Plášil ${ }^{2} \mathbb{D}$ \\ 1 Crystallography Department, Institute of Earth Sciences, St. Petersburg State University, University Emb. 7/9, \\ 199034 St. Petersburg, Russia; kalashnikova.soff@gmail.com (S.A.K.); st054910@student.spbu.ru (I.V.K.) \\ 2 Institute of Physics ASCR, v.v.i., Na Slovance 2, 18221 Praha 8, Czech Republic; plasil@fzu.cz \\ * Correspondence: vladislav.gurzhiy@spbu.ru or vladgeo17@mail.ru
}

Citation: Gurzhiy, V.V.;

Kalashnikova, S.A.; Kuporev, I.V.; Plášil, J. Crystal Chemistry and Structural Complexity of the Uranyl Carbonate Minerals and Synthetic Compounds. Crystals 2021, 11, 704 https://doi.org/10.3390/cryst11060704

Academic Editor: Duncan H. Gregory

Received: 18 May 2021

Accepted: 15 June 2021

Published: 19 June 2021

Publisher's Note: MDPI stays neutral with regard to jurisdictional claims in published maps and institutional affiliations.

Copyright: (C) 2021 by the authors. Licensee MDPI, Basel, Switzerland. This article is an open access article distributed under the terms and conditions of the Creative Commons Attribution (CC BY) license (https:/ / creativecommons.org/licenses/by/ $4.0 /)$

\begin{abstract}
Uranyl carbonates are one of the largest groups of secondary uranium(VI)-bearing natural phases being represented by 40 minerals approved by the International Mineralogical Association, overtaken only by uranyl phosphates and uranyl sulfates. Uranyl carbonate phases form during the direct alteration of primary $U$ ores on contact with groundwaters enriched by $\mathrm{CO}_{2}$, thus playing an important role in the release of $U$ to the environment. The presence of uranyl carbonate phases has also been detected on the surface of "lavas" that were formed during the Chernobyl accident. It is of interest that with all the importance and prevalence of these phases, about a quarter of approved minerals still have undetermined crystal structures, and the number of synthetic phases for which the structures were determined is significantly inferior to structurally characterized natural uranyl carbonates. In this work, we review the crystal chemistry of natural and synthetic uranyl carbonate phases. The majority of synthetic analogs of minerals were obtained from aqueous solutions at room temperature, which directly points to the absence of specific environmental conditions (increased $\mathrm{P}$ or $\mathrm{T}$ ) for the formation of natural uranyl carbonates. Uranyl carbonates do not have excellent topological diversity and are mainly composed of finite clusters with rigid structures. Thus the structural architecture of uranyl carbonates is largely governed by the interstitial cations and the hydration state of the compounds. The information content is usually higher for minerals than for synthetic compounds of similar or close chemical composition, which likely points to the higher stability and preferred architectures of natural compounds.
\end{abstract}

Keywords: uranyl; carbonate; mineral; crystal structure; topology; structural complexity

\section{Introduction}

Uranyl carbonate phases play a very important role in all processes related to the nuclear fuel cycle. This conjunction starts from U deposits, where uranyl carbonate minerals form during the direct alteration of primary U-bearing rocks (containing uraninite, etc.) under the influence of groundwaters enriched with $\mathrm{CO}_{2}$, which can be derived from the dissolution of host carbonate rocks or from the atmosphere [1-5]. In dissolved form, uranyl carbonates can play an important role in $U$ release to the environment. And of course, it should not be forgotten that uranyl-carbonate mineralization has been described among the alteration products of the "lavas" that were formed during the accident at the fourth reactor of the Chernobyl nuclear power plant in 1986 [6,7].

There are 40 uranyl carbonate mineral species approved by the International Mineralogical Association as of 1 November 2020, thus making this group one of the most representative among secondary uranium minerals, coming third only after phosphates and sulfates [8,9]. Despite a fairly large number of known compounds, the structural diversity is not as great as one might expect. It is also of interest that about a quarter of approved minerals still have their crystal structures undetermined. The amount of synthetic structurally characterized uranyl carbonates is inferior to natural phases but can give an idea of the crystallization conditions present in the environment. 
Current work is devoted to reviewing the topological diversity and growth conditions of natural uranyl carbonates and their synthetic analogs. Information-based complexity measures have been performed to determine contributions of various substructural building blocks and particular topological types into the complexity of the whole structure, which is related to the stability of a crystalline compound.

\section{Materials and Methods}

\subsection{Structural Data}

For the current review, all structural data deposited in the Inorganic Crystal Structure Database (ICSD; version 4.5.0; release February 2020) were selected and supplemented by the data reported in the most recent publications of the author of the current paper (J.P.). Chemical formulae, mineral names, and the basic crystallographic characteristics for all inorganic uranyl carbonates of both natural and synthetic origin are listed in Table 1. In addition, Table 1 contains information on the proposed symmetry and unit cell parameters for the uranyl carbonate minerals with yet undefined crystal structures listed in the IMA Database of Mineral Properties [10].

Table 1. Crystallographic characteristics of natural and synthetic uranyl carbonates.

\begin{tabular}{|c|c|c|c|c|c|c|c|}
\hline No. & Chemical Formula & Mineral Name & Sp.Gr. & $\begin{array}{l}a, \stackrel{\AA}{A} / \\
\alpha,{ }^{\circ}\end{array}$ & $\begin{array}{l}b, \AA ̊ \& / \\
\beta,{ }^{\circ}\end{array}$ & $\begin{array}{l}c, \stackrel{\AA}{\AA} / \\
\gamma, \stackrel{ }{\circ}\end{array}$ & Ref. \\
\hline \multicolumn{8}{|c|}{ Finite Clusters } \\
\hline \multicolumn{8}{|c|}{$c c 0-1: 2-9$} \\
\hline 1 & $\mathrm{~K}_{4}\left[\left(\mathrm{UO}_{2}\left(\mathrm{CO}_{3}\right)_{2}\left(\mathrm{O}_{2}\right)\right]\left(\mathrm{H}_{2} \mathrm{O}\right)\right.$ & & $P 2_{1} / n$ & $6.9670(14) / 90$ & $9.2158(18) / 91.511(3)$ & $18.052(4) / 90$ & [11] \\
\hline 2 & $\mathrm{~K}_{4}\left[\left(\mathrm{UO}_{2}\left(\mathrm{CO}_{3}\right)_{2}\left(\mathrm{O}_{2}\right)\right]\left(\mathrm{H}_{2} \mathrm{O}\right)_{2.5}\right.$ & & $P 2_{1} / n$ & $6.9077(14) / 90$ & $9.2332(18) / 91.310(4)$ & $21.809(4) / 90$ & [12] \\
\hline 3 & $\left(\mathrm{CN}_{3} \mathrm{H}_{6}\right)_{4}\left[\mathrm{UO}_{2}\left(\mathrm{CO}_{3}\right)_{2}\left(\mathrm{O}_{2}\right)\right] \cdot \mathrm{H}_{2} \mathrm{O}$ & & $P_{c a 2_{1}}$ & $15.883(1) / 90$ & $8.788(2) / 90$ & $16.155(1) / 90$ & [13] \\
\hline \multicolumn{8}{|c|}{$c c 0-1: 3-2$} \\
\hline 4 & $\mathrm{Na}_{4}\left(\mathrm{UO}_{2}\right)\left(\mathrm{CO}_{3}\right)_{3}$ & Čejkaite & $C_{c}$ & $9.2919(8) / 90$ & $16.0991(11) / 91.404(5)$ & $6.4436(3) / 90$ & [14] \\
\hline $4 \mathrm{a}$ & $\mathrm{Na}_{4}\left(\mathrm{UO}_{2}\right)\left(\mathrm{CO}_{3}\right)_{3}$ & & $P-3 c$ & $9.3417 / 90$ & $9.3417 / 90$ & $12.824 / 120$ & {$[15-17]$} \\
\hline $4 \mathrm{~b}$ & $\mathrm{Na}_{4}\left(\mathrm{UO}_{2}\right)\left(\mathrm{CO}_{3}\right)_{3}$ & $\begin{array}{c}\text { Cejkaite } \\
\text { old model }\end{array}$ & $P-1$ & $9.291(2) / 90.73(2)$ & $9.292(2) / 90.82(2)$ & $12.895(2) / 120.00(1)$ & [18] \\
\hline 5 & $\mathrm{~K}_{3} \mathrm{Na}\left(\mathrm{UO}_{2}\right)\left(\mathrm{CO}_{3}\right)_{3}$ & & $P-62 c$ & $9.29(2) / 90$ & $9.29(2) / 90$ & $8.26(2) / 120$ & [19] \\
\hline 6 & $\mathrm{~K}_{3} \mathrm{Na}\left(\mathrm{UO}_{2}\right)\left(\mathrm{CO}_{3}\right)_{3}\left(\mathrm{H}_{2} \mathrm{O}\right)$ & Grimselite & $P-62 c$ & $9.2507(1) / 90$ & $9.2507(1) / 90$ & $8.1788(1) / 120$ & {$[20-23]$} \\
\hline $6 a$ & $\mathrm{Rb}_{6} \mathrm{Na}_{2}\left(\left(\mathrm{UO}_{2}\right)\left(\mathrm{CO}_{3}\right)_{3}\right)_{2}\left(\mathrm{H}_{2} \mathrm{O}\right)$ & $\begin{array}{l}\mathrm{Rb} \text { analogue of } \\
\text { Grimselite }\end{array}$ & $P-62 c$ & $9.4316(7) / 90$ & $9.4316(7) / 90$ & $8.3595(8) / 120$ & [24] \\
\hline 7 & $\mathrm{~K}_{4}\left(\mathrm{UO}_{2}\right)\left(\mathrm{CO}_{3}\right)_{3}$ & Agricolaite & $\mathrm{C} 2 / \mathrm{c}$ & $10.2380(2) / 90$ & 9.1930(2)/95.108(2) & $12.2110(3) / 90$ & [25] \\
\hline $7 \mathbf{a}$ & $\mathrm{K}_{4} \mathrm{UO}_{2}\left(\mathrm{CO}_{3}\right)_{3}$ & & $\mathrm{C} 2 / \mathrm{c}$ & $10.247(3) / 90$ & $9.202(2) / 95.11(2)$ & $12.226(3) / 90$ & [26] \\
\hline $7 \mathbf{b}$ & $\mathrm{K}_{4}\left(\mathrm{UO}_{2}\right)\left(\mathrm{CO}_{3}\right)_{3}$ & & $\mathrm{C} 2 / \mathrm{c}$ & $10.240(7) / 90$ & $9.198(4) / 95.12(4)$ & $12.222(12) / 90$ & [27] \\
\hline 58 & $\mathrm{Rb}_{4}\left(\mathrm{UO}_{2}\right)\left(\mathrm{CO}_{3}\right)_{3}$ & & $\mathrm{C} 2 / \mathrm{c}$ & $10.778(5) / 90$ & $9.381(2) / 94.42(3)$ & $12.509(3) / 90$ & {$[28]$} \\
\hline 8 & $\mathrm{Cs}_{4} \mathrm{UO}_{2}\left(\mathrm{CO}_{3}\right)_{3}\left(\mathrm{H}_{2} \mathrm{O}\right)_{6}$ & & $P 2_{1} / n$ & $11.1764(4) / 90$ & 9.5703(4)/ 96.451(2) & $18.5756(7) / 90$ & [29] \\
\hline $8 a$ & $\mathrm{Cs}_{4}\left(\mathrm{UO}_{2}\left(\mathrm{CO}_{3}\right)_{3}\right)\left(\mathrm{H}_{2} \mathrm{O}\right)_{6}$ & & $P 2_{1} / n$ & $18.723(3) / 90$ & $9.647(2) / 96.84(1)$ & $11.297(2) / 90$ & [30] \\
\hline 9 & $\mathrm{Cs}_{4}\left(\mathrm{UO}_{2}\left(\mathrm{CO}_{3}\right)_{3}\right)$ & & $\mathrm{C} 2 / \mathrm{c}$ & $11.5131(9) / 90$ & $9.6037(8) / 93.767(2)$ & $12.9177(10) / 90$ & [31] \\
\hline 10 & $\left(\mathrm{NH}_{4}\right)_{4}\left(\mathrm{UO}_{2}\left(\mathrm{CO}_{3}\right)_{3}\right)$ & & $\mathrm{C} 2 / \mathrm{c}$ & $10.679(4) / 90$ & $9.373(2) / 96.43(2)$ & $12.850(3) / 90$ & [32] \\
\hline 11 & $\mathrm{Tl}_{4}\left(\left(\mathrm{UO}_{2}\right)\left(\mathrm{CO}_{3}\right)_{3}\right)$ & & $\mathrm{C} 2 / \mathrm{c}$ & $10.684(2) / 90$ & $9.309(2) / 94.95(2)$ & $12.726(3) / 90$ & [33] \\
\hline 12 & $\mathrm{Mg}_{2}\left(\mathrm{UO}_{2}\right)\left(\mathrm{CO}_{3}\right)_{3}\left(\mathrm{H}_{2} \mathrm{O}\right)_{18}$ & Bayleyite & $P 2_{1} / a$ & $26.560(3) / 90$ & $15.256(2) / 92.90(1)$ & $6.505(1) / 90$ & {$[34,35]$} \\
\hline 13 & $\mathrm{CaMg}\left(\mathrm{UO}_{2}\right)\left(\mathrm{CO}_{3}\right)_{3}\left(\mathrm{H}_{2} \mathrm{O}\right)_{12}$ & Swartzite & $P 2_{1} / m$ & $11.080(2) / 90$ & $14.634(2) / 99.43(1)$ & $6.439(1) / 90$ & {$[34,36,37]$} \\
\hline 14 & $\mathrm{Ca}_{2}\left(\mathrm{UO}_{2}\right)\left(\mathrm{CO}_{3}\right)_{3}\left(\mathrm{H}_{2} \mathrm{O}\right)_{11}$ & Liebigite & $B b a 2$ & $16.699(3) / 90$ & $17.557(3) / 90$ & $13.697(3) / 90$ & [34,38-40] \\
\hline 15 & $\mathrm{Ca}_{9}\left(\mathrm{UO}_{2}\right)_{4}\left(\mathrm{CO}_{3}\right)_{13} \cdot 28 \mathrm{H}_{2} \mathrm{O}$ & Markeyite & Ртmп & $17.9688(13)$ & $18.4705(6)$ & $10.1136(4)$ & [41] \\
\hline 16 & $\mathrm{Ca}_{8}\left(\mathrm{UO}_{2}\right)_{4}\left(\mathrm{CO}_{3}\right)_{12} \cdot 21 \mathrm{H}_{2} \mathrm{O}$ & Pseudomarkeyite & $P 2_{1} / m$ & $17.531(3)$ & $18.555(3)$ & $9.130(3) / 103.95(3)$ & [42] \\
\hline 17 & $\left.\mathrm{Sr}_{2} \mathrm{UO}_{2}\left(\mathrm{CO}_{3}\right)_{3}\right)\left(\mathrm{H}_{2} \mathrm{O}\right)_{8}$ & & $P 2_{1} / c$ & $11.379(2) / 90$ & $11.446(2) / 93.40(1)$ & $25.653(4) / 90$ & [43] \\
\hline 18 & $\mathrm{Na}_{6} \mathrm{Mg}\left(\mathrm{UO}_{2}\right)_{2}\left(\mathrm{CO}_{3}\right)_{6} \cdot 6 \mathrm{H}_{2} \mathrm{O}$ & Leószilárdite & $\mathrm{C} 2 / m$ & $11.6093(21) / 90$ & $6.7843(13) / 91.378(3)$ & $15.1058(28) / 90$ & [44] \\
\hline 19 & $\mathrm{Na}_{2} \mathrm{Ca}\left(\mathrm{UO}_{2}\right)\left(\mathrm{CO}_{3}\right)_{3}\left(\mathrm{H}_{2} \mathrm{O}\right)_{5.3}$ & Andersonite & $R-3 m$ & $17.8448(4) / 90$ & $17.8448(4) / 90$ & $23.6688(6) / 120$ & {$[20,34,38,45-55]$} \\
\hline 20 & $\mathrm{Na}_{2} \mathrm{Ca}_{8}\left(\mathrm{UO}_{2}\right)_{4}\left(\mathrm{CO}_{3}\right)_{13} \cdot 27 \mathrm{H}_{2} \mathrm{O}$ & Natromarkeyite & Pmmn & $17.8820(13)$ & $18.3030(4)$ & $10.2249(3)$ & [42] \\
\hline 21 & $\begin{array}{c}\mathrm{Ca}_{3} \mathrm{Na}_{1.5}\left(\mathrm{H}_{3} \mathrm{O}\right)_{0.5}\left(\mathrm{UO}_{2}(\mathrm{C}\right. \\
\left.\left.\mathrm{O}_{3}\right)_{3}\right)_{2}\left(\mathrm{H}_{2} \mathrm{O}\right)_{8}\end{array}$ & & Pnnm & $18.150(3) / 90$ & $16.866(6) / 90$ & $18.436(3) / 90$ & [56] \\
\hline 22 & $\mathrm{~K}_{2} \mathrm{Ca}\left(\mathrm{UO}_{2}\right)\left(\mathrm{CO}_{3}\right)_{3} \cdot 6 \mathrm{H}_{2} \mathrm{O}$ & Braunerite & $P 2_{1} / c$ & $17.6725(12) / 90$ & $11.6065(5) / 101.780(8)$ & $29.673(3) / 90$ & [57] \\
\hline 23 & $\mathrm{~K}_{2} \mathrm{Ca}_{3}\left[\left(\mathrm{UO}_{2}\right)\left(\mathrm{CO}_{3}\right)_{3}\right]_{2} \cdot 8\left(\mathrm{H}_{2} \mathrm{O}\right)$ & Linekite & Pnnm & $17.0069(5) / 90$ & $18.0273(5) / 90$ & $18.3374(5) / 90$ & [58] \\
\hline $23 a$ & $\mathrm{~K}_{2} \mathrm{Ca}_{3}\left(\left(\mathrm{UO}_{2}\left(\mathrm{CO}_{3}\right)_{3}\right)_{2}\left(\mathrm{H}_{2} \mathrm{O}\right)_{6}\right.$ & & Pnпm & $17.015(2) / 90$ & $18.048(2) / 90$ & $18.394(2) / 90$ & [59] \\
\hline 24 & $\operatorname{SrMg}\left(\mathrm{UO}_{2}\right)\left(\mathrm{CO}_{3}\right)_{3}\left(\mathrm{H}_{2} \mathrm{O}\right)_{12}$ & Swartzite-(Sr) & $P 2_{1} / m$ & $11.216(2) / 90$ & $14.739(2) / 99.48(1)$ & $6.484(1) / 90$ & {$[34,36]$} \\
\hline 25 & 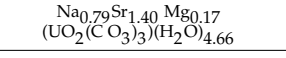 & & $P a-3$ & $20.290(3) / 90$ & $20.290(3) / 90$ & $20.290(3) / 90$ & [60] \\
\hline 26 & $\begin{array}{c}\mathrm{MgCa}_{5} \mathrm{Cu}_{2}\left(\mathrm{UO}_{2}\right)_{4}\left(\mathrm{CO}_{3}\right)_{12} \\
\left(\mathrm{H}_{2} \mathrm{O}_{33}\right.\end{array}$ & Paddlewheelite & $P_{c}$ & $22.052(4) / 90$ & $17.118(3) / 90.474(2)$ & $19.354(3) / 90$ & [61] \\
\hline
\end{tabular}


Table 1. Cont.

\begin{tabular}{|c|c|c|c|c|c|c|c|}
\hline No. & Chemical Formula & Mineral Name & Sp.Gr. & $a, \stackrel{\AA}{\AA} /$ & $b, \stackrel{\AA}{\AA} /$ & $\begin{array}{l}c, \stackrel{\AA}{\mathrm{A} /} \\
\gamma,\end{array}$ & Ref. \\
\hline 27 & $\mathrm{Na}_{8}\left[\left(\mathrm{UO}_{2}\right)\left(\mathrm{CO}_{3}\right)_{3}\right]\left(\mathrm{SO}_{4}\right)_{2} \cdot 3 \mathrm{H}_{2} \mathrm{O}$ & Ježekite & $P-62 m$ & $9.0664(11) / 90$ & $9.0664(11) / 90$ & $6.9110(6) / 120$ & [62] \\
\hline 28 & $\begin{array}{c}\mathrm{NaCa}_{3}\left(\mathrm{UO}_{2}\right)\left(\mathrm{CO}_{3}\right)_{3} \\
\left(\mathrm{SO}_{4}\right) \mathrm{F}\left(\mathrm{H}_{2} \mathrm{O}\right)_{10}\end{array}$ & Schröckingerite & $P-1$ & 9.634(1)/91.41(1) & $9.635(1) / 92.33(1)$ & $14.391(2) / 120.26(1)$ & {$[34,63-66]$} \\
\hline 29 & $\begin{array}{c}\mathrm{MgCa}_{4} \mathrm{~F}_{2}\left[\mathrm{UO}_{2}\left(\mathrm{CO}_{3}\right)_{3}\right]_{2} \\
\left(\mathrm{H}_{2} \mathrm{O}\right)_{17.29}\end{array}$ & Albrechtschraufite & $P-1$ & $13.569(2) / 115.82(1)$ & $13.419(2) / 107.61(1)$ & $11.622(2) / 92.84(1)$ & {$[67,68]$} \\
\hline 30 & $\begin{array}{c}\mathrm{Ca}_{5}\left(\mathrm{UO}_{2}\left(\mathrm{CO}_{3}\right)_{3}\right)_{2}\left(\mathrm{NO}_{3}\right)_{2} \\
\left(\mathrm{H}_{2} \mathrm{O}\right)_{10}\end{array}$ & & $P 2_{1} / n$ & $6.5729(9) / 90$ & $16.517(2) / 90.494(3)$ & $15.195(2) / 90$ & [69] \\
\hline 31 & $\mathrm{Ca}_{6}\left(\mathrm{UO}_{2}\left(\mathrm{CO}_{3}\right)_{3}\right)_{2} \mathrm{C}_{14}\left(\mathrm{H}_{2} \mathrm{O}\right)_{19}$ & & $P 4 / \mathrm{mbm}$ & $16.744(2) / 90$ & $16.744(2) / 90$ & $8.136(1) / 90$ & [69] \\
\hline 32 & $\mathrm{Ca}_{12}\left(\mathrm{UO}_{2}\left(\mathrm{CO}_{3}\right)_{3}\right)_{4} \mathrm{C}_{18}\left(\mathrm{H}_{2} \mathrm{O}\right)_{47}$ & & $F d-3$ & $27.489(3) / 90$ & $27.489(3) / 90$ & $27.489(3) / 90$ & [69] \\
\hline 33 & $\begin{array}{c}\mathrm{Nd}_{2} \mathrm{Ca}\left[\left(\mathrm{UO}_{2}\right)\left(\mathrm{CO}_{3}\right)_{3}\right]\left(\mathrm{CO}_{3}\right)_{2} \\
\left(\mathrm{H}_{2} \mathrm{O}\right)_{10.5}\end{array}$ & Shabaite-(Nd) & $P-1$ & $8.3835(5) / 90.058(3)$ & $9.2766(12) / 89.945(4)$ & $31.7519(3) / 90.331(4)$ & {$[70,71]$} \\
\hline 34 & {$\left[\mathrm{C}\left(\mathrm{NH}_{2}\right)_{3}\right]_{4}\left[\mathrm{UO}_{2}\left(\mathrm{CO}_{3}\right)_{3}\right]$} & & $R 3$ & $12.3278(1) / 90$ & $12.3278(1) / 90$ & $11.4457(2) / 120$ & [72] \\
\hline 35 & $\left(\mathrm{C}_{4} \mathrm{H}_{12} \mathrm{~N}\right)_{4}\left[\mathrm{UO}_{2}\left(\mathrm{CO}_{3}\right)_{3}\right] \cdot 8 \mathrm{H}_{2} \mathrm{O}$ & & $P 2_{1} / n$ & $10.5377(18) / 90$ & $12.358(2) / 99.343(4)$ & $28.533(5) / 90$ & [73] \\
\hline \multicolumn{8}{|c|}{$c c 0-1: 2-10$} \\
\hline 36 & $\begin{array}{c}{\left[\mathrm{C}\left(\mathrm{NH}_{2}\right)_{3}\right]_{6}\left[\left(\mathrm{UO}_{2}\right)_{3}\left(\mathrm{CO}_{3}\right)_{6}\right]} \\
\left(\mathrm{H}_{2} \mathrm{O}\right)_{6.5}\end{array}$ & & $P-1$ & $6.941(2) / 95.63(2)$ & $14.488(2) / 98.47(2)$ & $22.374(2) / 101.88(2)$ & [74] \\
\hline \multicolumn{8}{|c|}{ Nanoclusters } \\
\hline 37 & $\begin{array}{c}\mathrm{Mg}_{8} \mathrm{Ca}_{8}\left(\mathrm{UO}_{2}\right)_{24}\left(\mathrm{CO}_{3}\right)_{30} \mathrm{O}_{4} \\
(\mathrm{OH})_{12}\left(\mathrm{H}_{2} \mathrm{O}\right)_{138}\end{array}$ & Ewingite & $I 4_{1} / a c d$ & $35.142(2) / 90$ & $35.142(2) / 90$ & $47.974(3) / 90$ & [75] \\
\hline \multicolumn{8}{|c|}{ Layers } \\
\hline \multicolumn{8}{|c|}{$5^{4} 4^{2}{ }^{4}\left(\beta-U_{3} O_{8}\right)$} \\
\hline 38 & $\begin{array}{c}\mathrm{CaU}\left(\mathrm{UO}_{2}\right)_{2}\left(\mathrm{CO}_{3}\right) \mathrm{O}_{4}(\mathrm{OH}) \\
\left(\mathrm{H}_{2} \mathrm{O}\right)_{7}\end{array}$ & Wyartite & $P 2_{1} 2_{1} 2_{1}$ & $11.2706(8) / 90$ & $7.1055(5) / 90$ & $20.807(1) / 90$ & {$[76-78]$} \\
\hline $38 \mathrm{a}$ & $\begin{array}{c}\mathrm{Ca}\left(\mathrm{U}\left(\mathrm{UO}_{2}\right)_{2}\left(\mathrm{CO}_{3}\right)_{0.7} \mathrm{O}_{4}(\mathrm{OH})_{1.6}\right) \\
\left(\mathrm{H}_{2} \mathrm{O}\right)_{1.63}\end{array}$ & $\begin{array}{c}\text { Wyartite } \\
\text { dehydrated }\end{array}$ & Pmcn & $11.2610(6) / 90$ & $7.0870(4) / 90$ & $16.8359(10) / 90$ & [79] \\
\hline \multicolumn{8}{|c|}{$6^{1} 5^{2} 4^{2} 3^{2}$ (phosphuranylite) } \\
\hline 39 & $\mathrm{Ca}\left(\mathrm{UO}_{2}\right)_{3}\left(\mathrm{CO}_{3}\right)_{2} \mathrm{O}_{2}\left(\mathrm{H}_{2} \mathrm{O}\right)_{6}$ & Fontanite & $P 2_{1} / n$ & $6.968(3) / 90$ & $17.276(7) / 90.064(6)$ & $15.377(6) / 90$ & {$[80,81]$} \\
\hline \multicolumn{8}{|c|}{$6^{1} 5^{2} 4^{2} 3^{6}$ (roubaultite) } \\
\hline 40 & $\begin{array}{c}\mathrm{Cu}_{2}\left(\mathrm{UO}_{2}\right)_{3}\left(\mathrm{CO}_{3}\right)_{2} \mathrm{O}_{2}(\mathrm{OH})_{2} \\
\left(\mathrm{H}_{2} \mathrm{O}\right)_{4}\end{array}$ & Roubaultite & $P-1$ & $7.767(3) / 92.16(4)$ & $6.924(3) / 90.89(4)$ & $7.850(3) / 93.48(4)$ & {$[82,83]$} \\
\hline \multicolumn{8}{|c|}{$6^{1} 3^{2}-\mathrm{I}$ (rutherfordine) } \\
\hline 41 & $\left(\mathrm{UO}_{2}\right)\left(\mathrm{CO}_{3}\right)$ & Rutherfordine & $\operatorname{Imm} 2$ & $4.840(1) / 90$ & $9.273(2) / 90$ & $4.298(1) / 90$ & [20,84-87] \\
\hline 42 & $\mathrm{Ca}\left(\mathrm{H}_{2} \mathrm{O}\right)_{3}\left[\left(\mathrm{UO}_{2}\right)_{3}\left(\mathrm{CO}_{3}\right)_{3.6} \mathrm{O}_{0.2}\right]$ & Sharpite & $\mathrm{Cmcm}$ & $4.9032(4)$ & $15.6489(11)$ & $22.0414(18)$ & [88] \\
\hline $42 \mathrm{a}$ & $\mathrm{Ca}\left(\mathrm{UO}_{2}\right)_{6}\left(\mathrm{CO}_{3}\right)_{5}(\mathrm{OH})_{4} \cdot 6 \mathrm{H}_{2} \mathrm{O}$ & Sharpite & Orth & $21.99(2)$ & $15.63(2)$ & $4.487(4)$ & {$[89,90]$} \\
\hline \multicolumn{8}{|c|}{$6^{1} 3^{2}$-II (widenmannite) } \\
\hline 43 & $\mathrm{~Pb}_{2}\left[\left(\mathrm{UO}_{2}\right)\left(\mathrm{CO}_{3}\right)_{2}\right]$ & Widenmannite & Pmmn & $4.9350(7) / 90$ & $9.550(4) / 90$ & $8.871(1) / 90$ & {$[21,91-93]$} \\
\hline \multicolumn{8}{|c|}{ Layers of Miscellaneous Topology } \\
\hline 44 & $\mathrm{Y}_{2}\left(\mathrm{UO}_{2}\right)_{4}\left(\mathrm{CO}_{3}\right)_{3} \mathrm{O}_{4} \cdot 14 \mathrm{H}_{2} \mathrm{O}$ & Kamotoite-(Y) & $P 2_{1} / n$ & $12.3525(5)$ & $12.9432(5) / 99.857(3)$ & $19.4409(7)$ & {$[94,95]$} \\
\hline 45 & $\begin{array}{c}{\left[\left(\mathrm{Y}_{4.22} \mathrm{Nd}_{3.78}\right)\left(\mathrm{H}_{2} \mathrm{O}\right)_{25}\left(\mathrm{UO}_{2}\right)_{16} \mathrm{O}_{8}\right.} \\
\left.(\mathrm{OH})_{8}\left(\mathrm{CO}_{3}\right)_{16}\right]\left(\mathrm{H}_{2} \mathrm{O}\right)_{14}\end{array}$ & Bijvoetite-(Y) & $B 2_{1}$ & $21.234(3) / 90$ & $12.958(2) / 90.00(2)$ & $44.911(7) / 90$ & {$[96,97]$} \\
\hline 46 & $\mathrm{Ca}\left(\mathrm{UO}_{2}\right)\left(\mathrm{CO}_{3}\right)_{2} \cdot 5 \mathrm{H}_{2} \mathrm{O}$ & Meyrowitzite & $P 2_{1} / n$ & $12.376(3)$ & $16.0867(14) / 107.679(13)$ & $20.1340(17)$ & [98] \\
\hline \multicolumn{8}{|c|}{ Minerals with Undefined Structures } \\
\hline 47 & $\begin{array}{c}\mathrm{Cu}_{2}(\mathrm{Ce}, \mathrm{Nd}, \mathrm{La})_{2}\left(\mathrm{UO}_{2}\right)\left(\mathrm{CO}_{3}\right)_{5} \\
(\mathrm{OH})_{2} \cdot 1.5 \mathrm{H} 2 \mathrm{O}\end{array}$ & Astrocyanite-(Ce) & Hex & $14.96(2) / 90$ & $14.96(2) / 90$ & $26.86(4) / 120$ & [99] \\
\hline 48 & $\left(\mathrm{UO}_{2}\right)\left(\mathrm{CO}_{3}\right) \cdot \mathrm{H}_{2} \mathrm{O}$ & Blatonite & Hex or Trig & $15.79(1) / 90$ & $15.79(1) / 90$ & $23.93(3) / 120$ & [100] \\
\hline 49 & $\left(\mathrm{UO}_{2}\right)\left(\mathrm{CO}_{3}\right) \cdot \mathrm{nH}_{2} \mathrm{O}$ & Joliotite & Orth & 8.16 & 10.35 & 6.32 & [21] \\
\hline 50 & $\begin{array}{c}\mathrm{CaGd}_{2}\left(\mathrm{UO}_{2}\right)_{24}\left(\mathrm{CO}_{3}\right)_{8} \mathrm{Si}_{4} \mathrm{O}_{28} . \\
60 \mathrm{H}_{2} \mathrm{O}\end{array}$ & Lepersonnite-(Gd) & Pnnm or Pnn2 & $16.23(3) / 90$ & $38.74(9) / 90$ & $11.73(3) / 90$ & [96] \\
\hline 51 & $\mathrm{Ca}\left(\mathrm{UO}_{2}\right)\left(\mathrm{CO}_{3}\right)_{2} \cdot 3 \mathrm{H}_{2} \mathrm{O}$ & Metazellerite & $P b n 2_{1}$ or $P b n m$ & $9.718(5)$ & $18.226(9)$ & $4.965(4)$ & [101] \\
\hline 52 & $\left(\mathrm{UO}_{2}\right)_{2}\left(\mathrm{CO}_{3}\right)(\mathrm{OH})_{2} \cdot 4 \mathrm{H}_{2} \mathrm{O}$ & Oswaldpeetersite & $P 2_{1} / c$ & $4.1425(6)$ & $14.098(3) / 103.62(1)$ & $18.374(5)$ & [102] \\
\hline 53 & $\begin{array}{c}\mathrm{Ca}_{3} \mathrm{Mg}_{3}\left(\mathrm{UO}_{2}\right)_{2}\left(\mathrm{CO}_{3}\right)_{6}(\mathrm{OH})_{4} \\
18 \mathrm{H}_{2} \mathrm{O}\end{array}$ & Rabbitite & Mon & $32.6(1)$ & $23.8(1) / \sim 90$ & $9.45(5)$ & [103] \\
\hline 54 & $\mathrm{Ca}\left(\mathrm{UO}_{2}\right)_{3}\left(\mathrm{CO}_{3}\right)(\mathrm{OH})_{6} \cdot 3 \mathrm{H}_{2} \mathrm{O}$ & Urancalcarite & $\mathrm{Pbnm}$ or $\mathrm{Pbn} 2_{1}$ & $15.42(3)$ & $16.08(4)$ & $6.970(6)$ & [104] \\
\hline 55 & $\mathrm{Ca}_{2} \mathrm{Cu}\left(\mathrm{UO}_{2}\right)\left(\mathrm{CO}_{3}\right)_{4} \cdot 6 \mathrm{H}_{2} \mathrm{O}$ & Voglite & $P 2_{1}$ or $P 2_{1} / m$ & 25.97 & $24.50 / 104.0$ & 10.70 & {$[105,106]$} \\
\hline 56 & $\mathrm{Ca}\left(\mathrm{UO}_{2}\right)\left(\mathrm{CO}_{3}\right)_{2} \cdot 5 \mathrm{H}_{2} \mathrm{O}$ & Zellerite & $P m n 2_{1}$ or $P m n m$ & $11.220(15)$ & $19.252(16)$ & $4.933(16)$ & {$[101,107]$} \\
\hline 57 & $\begin{array}{c}\mathrm{CaZn}_{11}\left(\mathrm{UO}_{2}\right)\left(\mathrm{CO}_{3}\right)_{3}(\mathrm{OH})_{20} \\
4 \mathrm{H}_{2} \mathrm{O}\end{array}$ & Znucalite & Orth & $10.72(1)$ & $25.16(1)$ & $6.325(4)$ & [108] \\
\hline $57 a$ & $\underset{4 \mathrm{H}_{2} \mathrm{O}}{\mathrm{CaZn}_{12}\left(\mathrm{UO}_{2}\right)\left(\mathrm{CO}_{3}\right)_{3}(\mathrm{OH})_{22}}$ & Znucalite & Tricl & $12.692(4) / 89.08(2)$ & $25.096(6) / 91.79(2)$ & $11.685(3) / 90.37(3)$ & [109] \\
\hline
\end{tabular}

\subsection{Graphical Representation and Anion Topologies}

The crystal structures of uranyl carbonate minerals and synthetic compounds discussed in the current review are based on the finite clusters, chains, layers, and even nanoclusters built by the linkage of U-centered coordination polyhedra with each other and carbonate groups. $\mathrm{U}(\mathrm{VI})$ atoms make two short $\mathrm{U}^{6+} \equiv \mathrm{O}^{2-}$ bonds to form approximately 
linear $\mathrm{UO}_{2}{ }^{2+}$ uranyl cations $(\mathrm{Ur})$, which are in turn surrounded in the equatorial plane by other four-to-six $\mathrm{O}$ atoms, resulting in the formation of a tetra-, penta-, or hexagonal bipyramid, as a coordination polyhedron of $\mathrm{U}(\mathrm{VI})$ atoms. The carbonate group is the simplest oxocarbon anion with $\mathrm{C}$ atom arranged in the center of a flat triangle and $\mathrm{O}$ atoms occupying all three of its vertices.

Topological analysis of the uranyl carbonate structural complexes is based on the description of $\mathrm{Ur}$ and $\mathrm{CO}_{3}$ interpolyhedral linkage. The topology of the uranyl carbonate finite clusters and chains can be described using the theory of graphical (nodal) representation, which was first proposed by Hawthorne [110], and subsequently modified by Krivovichev [111,112], in which black and white nodes correspond to $U r$ and $\mathrm{CO}_{3}$ groups, respectively; and the single or double line between the nodes corresponds to a vertex- or edge-sharing way of polyhedra polymerization, respectively (Figure 1a-c). Anion topology approach was proposed by Burns and co-authors [113,114] to describe the U-bearing crystal structures that are based upon sheets with edge-sharing linkage. To obtain anion topology of the layer, all cations, $\mathrm{O}_{U r}$, and $\mathrm{O}$ atoms coordinating only one cation should be removed, while the rest of $\mathrm{O}$ atoms should be linked via single lines up to c.a. $3.5 \AA$ length (Figure $1 \mathrm{~d}-\mathrm{f}$ ). The black-and-white graph is labeled with a special index $c c \mathrm{D}-\mathrm{U}: \mathrm{CO}_{3}$ \#, where $c c$ means "cation-centered", D specifies dimensionality (0-finite clusters, 1 -chains and 2-sheets), $\mathrm{U}: \mathrm{CO}_{3}$ ratio, \#-registration number of the unit. Sheet-anion topology is indicated by the ring symbol, $p_{1}{ }^{r 1} p_{2}{ }^{r 2} \ldots$, where $p$ is the number of vertices in a topological cycle, and $r$ is the amount of the respective cycle in the reduced section of the sheet.

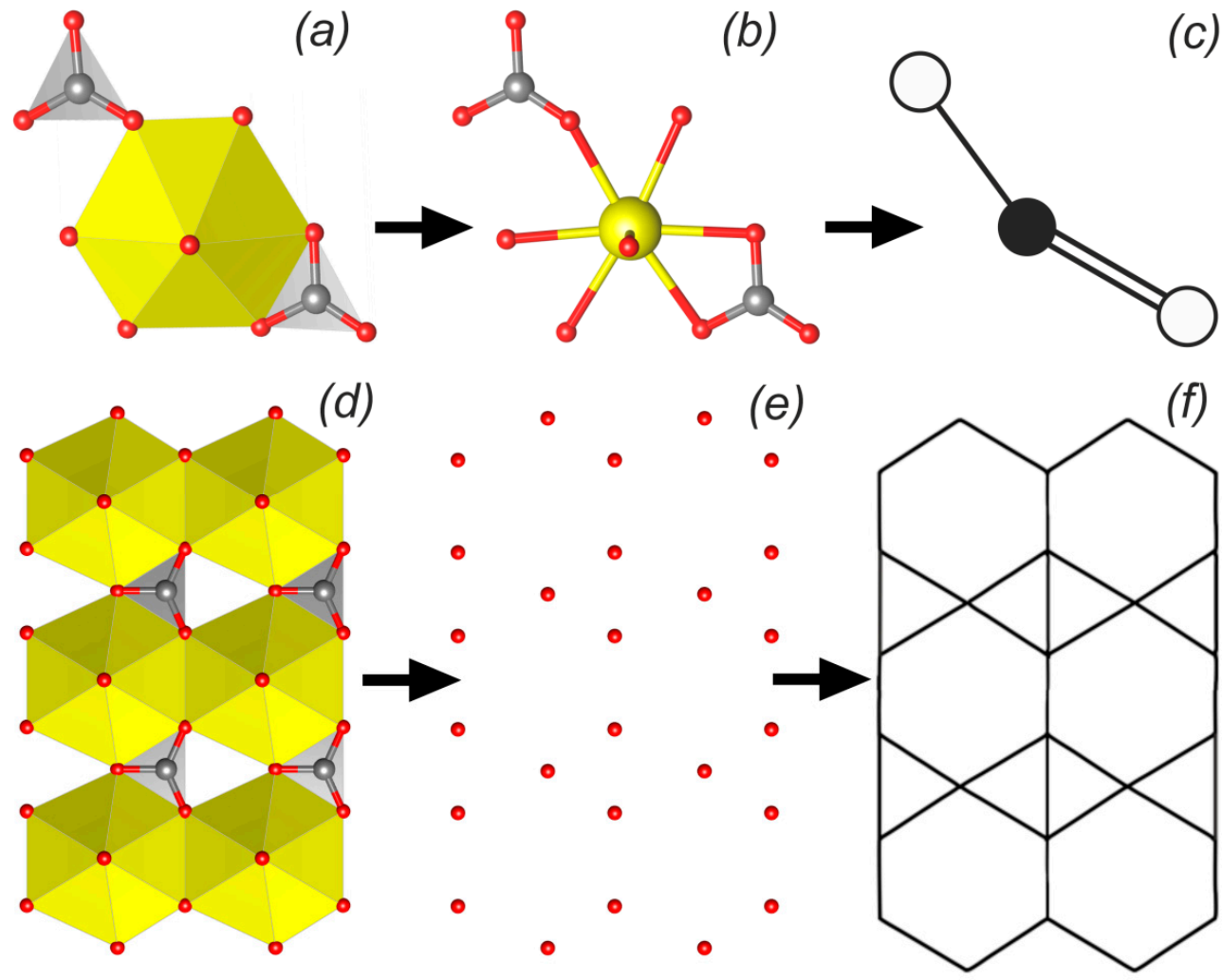

Figure 1. Illustration of building topologies. Combination of $U r$ bipyramid with edge- and vertex-shared triangular carbonate groups in polyhedral (a), ball-and-stick (b) representations, and respective black-and-white graph (c). Fragment of the dense uranyl-carbonate layer with edge-sharing interpolyhedral linkage (d), $\mathrm{O}$ atoms that are involved in linkage with more than one cation (e), and the resulted anion topology built on them (f). Legend: U-bearing coordination polyhedra $=$ yellow $; \mathrm{U}$ atoms $=$ yellow $; \mathrm{C}$ atoms $=$ grey; $\mathrm{O}$ atoms $=$ red; black nodes $=\mathrm{U}$ atoms, white nodes $=\mathrm{C}$ atoms; $\mathrm{CO}_{3}$ groups are shown in a ball-and-stick model with grey filling; see Section 2.2 for details. 


\subsection{Complexity Calculations}

Structural complexity calculations allow to compare the structures and quantitatively characterize the impact of each substructural unit (i.e., U-bearing complex, interstitial cations, hydration state, etc.) in terms of their information content on the formation of a particular architecture. This approach was recently developed by Krivovichev [115-119], successfully implemented in a number of works (e.g., [120-123]), and is based on the Shannon information content calculations of per atom $\left(I_{G}\right)$ and per unit cell $\left(I_{G, t o t a l}\right)$ using the following equations:

$$
\begin{gathered}
I_{G}=-\sum_{i=1}^{k} p_{i} \log _{2} p_{i} \quad \text { (bits/atom) } \\
I_{G, \text { total }}=-v I_{G}=-v \sum_{i=1}^{k} p_{i} \log _{2} p_{i} \quad(\text { bits } / \text { cell })
\end{gathered}
$$

where $k$ is the number of different crystallographic orbits (independent sites) in the structure and $p_{i}$ is the random choice probability for an atom from the $i$-th crystallographic orbit, that is:

$$
p_{i}=m_{i} / v
$$

where $m_{i}$ is a multiplicity of a crystallographic orbit (i.e., the number of atoms of a specific Wyckoff site in the reduced unit cell), and $v$ is the total number of atoms in the reduced unit cell.

The direct comparison of complexity parameters is possible only for the structures with identical or very close chemical composition (e.g., polymorphs), while changes in hydration state or interstitial complexes could significantly affect the overall complexity behavior. Thus, the structural complexity parameters of various building blocks (uranyl carbonate units, interstitial structure, H-bonding system) were calculated according to the recently suggested algorithm [124-127], so-called "ladders of information", to analyze their contributions into the complexity of the whole structure, and to distinguish which of the blocks plays the most important role, and which has the most influence on symmetry preservation or reduction.

\section{Results}

\subsection{Uranyl Carbonate Minerals}

Uranyl carbonates are one of the most abundant $\mathrm{U}(\mathrm{VI})$-containing minerals at the Earth's surface or near the surface. Their crystallization is possible due to ubiquitous $\mathrm{CO}_{2}$ dissolved in percolating aqueous solutions and can also be amplified by the dissolution of the carbonate minerals in the rock or hydrothermal veins (such as calcite or dolomite). Uranyl-carbonate aqueous species can be important constituents of groundwater under neutral to alkaline conditions as being thermodynamically favored $[128,129]$. Under such $\mathrm{pH}$ conditions, the dominating aqueous species are uranyl monocarbonate, $\left(\mathrm{UO}_{2}\right)\left(\mathrm{CO}_{3}\right)^{0}$, uranyl dicarbonate, $\left(\mathrm{UO}_{2}\right)\left(\mathrm{CO}_{3}\right)_{2}{ }^{2-}$, and uranyl tricarbonate, $\left(\mathrm{UO}_{2}\right)\left(\mathrm{CO}_{3}\right)_{3}{ }^{4-}$, with $\mathrm{pK}$ values of 5.5, 7, and 9, respectively [128]. The precipitation of solid phases from the solutions is usually connected with a higher evaporation rate or local oversaturation. Abandoned mining tunnels and adits can serve us as a model for such a situation. Efflorescences of uranyl carbonate minerals precipitating on the mining walls are typical indicators of uranium mineralization in closer or larger distances. Such precipitates have been found hundreds of meters far from the primary U mineralization in the mines (as e.g., in Jáchymov, Czech Republic).

In general, from a genetical point of view and considering the processes that led to the uranyl carbonate formation, we can distinguish among the two groups of uranyl carbonate minerals. The first comprises primary uranyl carbonates, or those that are connected genetically somewhat more with the primary mineralization. The second then comprises a group of uranyl carbonates of the recent or sub-recent origin, usually formed 
as the precipitates on the walls of the mining adits. Minerals are present, such as sharpite, $\mathrm{Ca}\left[\left(\mathrm{UO}_{2}\right)_{3} \mathrm{O}_{0.2}\left(\mathrm{CO}_{3}\right)_{3.6}\right]\left(\mathrm{H}_{2} \mathrm{O}\right)_{3}[88,89]$, roubaultite, $\mathrm{Cu}_{2}\left[\left(\mathrm{UO}_{2}\right)_{3}\left(\mathrm{CO}_{3}\right)_{2}(\mathrm{OH})_{2}\right]\left(\mathrm{H}_{2} \mathrm{O}\right)_{4}$ [83] or fontanite, $\mathrm{Ca}\left[\left(\mathrm{UO}_{2}\right)_{3}\left(\mathrm{CO}_{3}\right)_{2} \mathrm{O}_{2}\right]\left(\mathrm{H}_{2} \mathrm{O}\right)_{6}[81,96]$. These minerals are usually tightly spatially connected either with primary minerals (even in relics) or other $\mathrm{U}(\mathrm{VI})$ non-carbonate supergene minerals, such as silicates of uranyl-oxides hydroxy-hydrate minerals. As the second, distinctive group, we can consider uranyl carbonate minerals such as grimselite, $\mathrm{K}_{3} \mathrm{Na}\left(\mathrm{UO}_{2}\right)\left(\mathrm{CO}_{3}\right)_{3}\left(\mathrm{H}_{2} \mathrm{O}\right)[22,23,130]$, bayleyite, $\mathrm{Mg}_{2}\left[\left(\mathrm{UO}_{2}\right)\left(\mathrm{CO}_{3}\right)_{3}\right]\left(\mathrm{H}_{2} \mathrm{O}\right)_{18}[34,35]$, or paddlewheelite, $\mathrm{MgCa}_{5} \mathrm{Cu}_{2}\left[\left(\mathrm{UO}_{2}\right)\left(\mathrm{CO}_{3}\right)_{3}\right]_{4}\left(\mathrm{H}_{2} \mathrm{O}\right)_{33}$ [61]. These are usually higher-hydrates oxysalts, tending to appear in powdery aggregates, efflorescence, or curved uneven crystals.

The first uranyl carbonate minerals were discovered in the 19th century. One of the first discovered was mineral liebigite, $\left.\mathrm{Ca}_{2}\left[\mathrm{UO}_{2}\right)\left(\mathrm{CO}_{3}\right)_{3}\right]\left(\mathrm{H}_{2} \mathrm{O}\right)_{\sim 11}[40,131]$, reported in 1848 from Turkey by J.B. Smith and named after German chemist Justus von Liebig. Subsequently, this mineral was more precisely described and characterized from Jáchymov in Czechia (those times a part of the Austro-Hungarian Empire) under the name Uran-calccarbonat, or Uranothallite, and then all were described to be the same mineral equal to liebigite [132]. Jáchymov became the famous and rich locality for many uranyl-carbonates. Many have been found there for the first time and thus Jáchymov remains one of the richest localities, even for the type uranyl carbonate minerals (from approximately $96 \mathrm{U}(\mathrm{VI})$ supergene minerals, 19 are uranyl carbonates, thus $20 \%$ and 10 of them are type-minerals).

Until ca. 2015, there were only U-carbonates from the hydrothermal Variscan-type of U-deposits studied more in detail. Since extensive sampling campaigns at the Red Canyon area (San Juan County, UT, USA) several new particularly interesting U-carbonates with novel structural features and topologies have been discovered [42,98]. As current studies document that at the more detailed scale (micro- to nano-sized), the mineralogy of the localities is of course more diverse than thought, new uranyl carbonates are likely to be discovered. Furthermore, the discovery of U-nano-cages-containing the mineral ewingite [75], has brought up questions about the possible role of nano-scale clusters and cages in the processes of dissolution and formation of uranyl carbonates and uranyl minerals in general. It may be necessary to account for such nano-cages in the geochemical models of particular uranium-bearing systems.

\subsection{Synthetic Uranyl Carbonates}

First of all, it should be noted that the number of synthetic phases for which the structures were determined is significantly inferior to the structurally characterized natural uranyl carbonates in the ratio of 19:32. Whereas for other groups of $\mathrm{U}(\mathrm{VI})$-bearing compounds this proportion is usually opposite $[8,127,133]$. The first structurally characterized synthetic uranyl carbonate, to our knowledge, was one of the simplest phases $4 \mathbf{a}$, sodiumbearing $\mathrm{Na}_{4}\left(\mathrm{UO}_{2}\right)\left(\mathrm{CO}_{3}\right)_{3}$ [17]. It is of interest that the first crystal structure of the natural uranyl carbonate, rutherfordine (41), was reported the year before [85]. The papers of $\mathrm{K}$. Mereiter from the TU Wien (Austria) should be certainly noted in the first row among the works devoted to the synthesis and structural studies of synthetic uranyl carbonates. Then, the studies carried out by the A.M. Fedoseev and I.A. Charushnikova from the Frumkin Institute of Physical chemistry and Electrochemistry RAS (Russian Federation) and by V.N. Serezhkin from the Samara State University (Russian Federation) should be mentioned. A substantial portion of the synthetic uranyl carbonate compounds was synthesized and studied by P. C. Burns and his colleagues from the University of Notre Dame (USA), who significantly contribute to the studies of uranyl carbonate minerals as well.

All synthetic experiments can be roughly divided into two groups. Moreover, the majority of inorganic uranyl carbonates were synthesized by evaporation at room temperature and only a few of them were obtained from hydrothermal conditions. Uranyl nitrate hexahydrate was usually used as the source of $\mathrm{U}$. But in some experiments, more specific reagents were used: $\mathrm{UO}_{2}$ powder (for 1 and 2), $\mathrm{UO}_{2}\left(\mathrm{CO}_{3}\right)$ (for $7 \mathbf{a}$ ), $\mathrm{Ag}_{4}\left[\mathrm{UO}_{2}\left(\mathrm{CO}_{3}\right)_{3}\right]$ (for 8a), $\alpha-\mathrm{UO}_{2} \mathrm{MoO}_{4}\left(\mathrm{H}_{2} \mathrm{O}\right)_{2}$ (for 10), and $\mathrm{Na}_{4} \mathrm{UO}_{2}\left(\mathrm{CO}_{3}\right)_{3}$ (for 21). Potassium, sodium, cesium, or thallium carbonates were used as the source of $\mathrm{CO}_{3}$ ions within the synthetic 
experiments. Compounds $\mathbf{3 6}$ and $\mathbf{1 0}$ can be considered as exceptions due to the usage of guanidine carbonate and carbamide in the respective syntheses. Several protocols of synthetic experiments deserve special attention. Thus, compound $\mathbf{1}$ [11] was formed as the result of the dissolution of $\mathrm{UO}_{2}$ powder in the solution of $\mathrm{K}_{2} \mathrm{CO}_{3}$ and $\mathrm{H}_{2} \mathrm{O}_{2}$ at room temperature. Later it was filtered through a $0.45 \mu \mathrm{m}$ polyamide syringe filter, and an additional $1.5 \mathrm{~mL}$ of $35 \mathrm{wt} \% \mathrm{H}_{2} \mathrm{O}_{2}$ was added. Afterward it was transferred to a borosilicate scintillation vial and layered with methanol. The compound 2 [12] was obtained similarly, except for the scintillation vial step. The crystals of 4a [16] were obtained by hydrothermal synthesis at $135{ }^{\circ} \mathrm{C}$ in a sealed silica glass tube at about $20 \mathrm{MPa}$. The compound 7a [27] was synthesized by evaporation at room temperature, but before being left to evaporate, the dissolution of the precipitate was achieved via heating the solution over a steam bath. The crystals of $\mathbf{7 b}[28]$ were obtained from the solution that was stirred for five days. The compound 11 [33] was synthesized by slow addition of uranyl nitrate solution to the solution of $\mathrm{Tl}_{2}\left(\mathrm{CO}_{3}\right)_{2}$ at the temperature of c.a. $57^{\circ} \mathrm{C}$. The solvent was removed in a vacuum desiccator for two months from the resulting yellow-green solution, and crystals were then taken from the precipitate. To obtain the crystals of $\mathbf{3 6}$ [74], the initial solution was stirred vigorously for several days, afterwards, it was centrifuged and the supernatant was removed via pipet. The crystals were obtained from the precipitate, which was slowly cooled to $5{ }^{\circ} \mathrm{C}$ under a $\mathrm{CO}_{2}$ atmosphere.

Nine of uranyl carbonate minerals have synthetic analog, which was also obtained mostly by evaporation at room temperature, except for the crystals of 7 [26], which were formed during the two months of evaporation at vacuum-desiccator. The compound 4a [15] was synthesized by hydrothermal reaction at $220{ }^{\circ} \mathrm{C}$. The crystals of 41 [20] were obtained by purging the solution of $\mathrm{UO}_{3}$ with $70 \mathrm{kPa} \mathrm{CO}_{2}$ at the glove box for $24 \mathrm{~h}$.

Very special attention can be paid to compound 4a [15], which may be the same sodium uranyl carbonate that was found among alteration products of the "lavas" resulting from the nuclear accident of the Chernobyl nuclear power plant [6,7].

\subsection{Topological Analysis}

The majority of uranyl carbonate crystal structures are based on finite clusters, which are represented by only two topological types (Table 1). The topological variety of layered uranyl carbonate complexes is significantly larger; however, the amount of compounds, which structures are based on the 2D units, is much lower. There are only ten uranyl carbonate compounds known with a layered structure, and all of them are natural phases.

The crystal structures of two synthetic K-bearing uranyl carbonates $\mathbf{1}$ [11] and 2 [12] differing only in the hydration state and one uranyl carbonate, templated by guanidinium molecules 3 [13], are based on the finite clusters of the $c c 0-1: 2-9$ topological type (Figure 2a,b). In terms of polyhedral representation, these clusters can be described as a hexagonal bipyramid that shares two of its equatorial edges with $\mathrm{CO}_{3}$ groups spaced by one non-shared equatorial edge. There is a peroxide molecule arranged in the equatorial plane spaced from a carbonate group by another non-shared edge. Such topological type was also described in the structures of two uranyl nitrate compounds, pure inorganic [134] and organically templated [135], in which the peroxide group was replaced by two $\mathrm{H}_{2} \mathrm{O}$ molecules. It should be noted that this topological type has an isomer, if two equatorial $\mathrm{CO}_{3}$ groups are trans-arranged, being spaced by two non-shared edges, in contrast to the cis-arrangement in the structures of 1-3. The trans-isomer is one of the most common types of uranyl nitrate finite clusters [136], while it has not been observed in the structures of uranyl carbonates at all.

Uranyl tricarbonate cluster (UTC), which is shown in Figure 2c, is the most common structural unit among the natural and synthetic uranyl carbonate phases. There are $39 \mathrm{com}-$ pounds known (Table 1), whose structures are based on these finite clusters, and is in sum 2.5 times more than the amount of all other structurally characterized uranyl carbonates (15). The topology of UTC belongs to the $c c 0-1: 3-2$ type (Figure 2d). This topology can be obtained from the previous cis-cc0-1:2-9 type by the replacement of the peroxide molecule 
by the third $\mathrm{CO}_{3}$ group, resulting in the formation of a triangular cluster with the uranyl hexagonal bipyramid arranged in its core and ideal $-6 m 2$ point group symmetry.

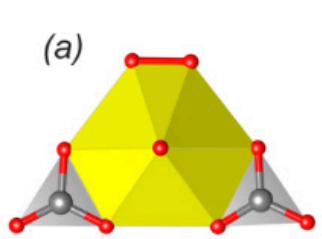

(b)
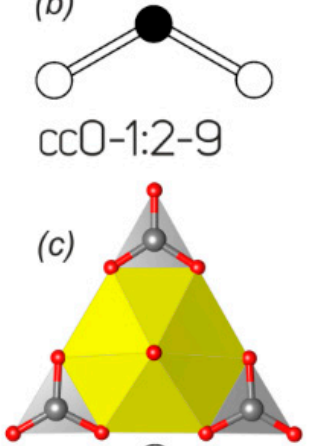

(d)

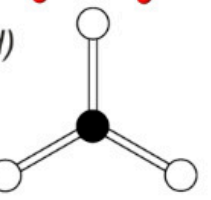

$\mathrm{ccO}-1: 3-2$
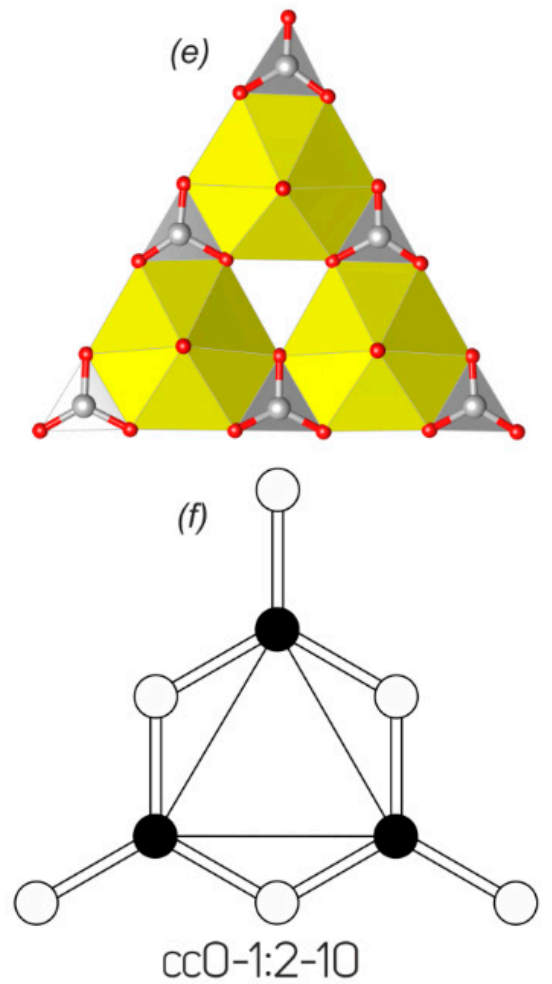

(g)

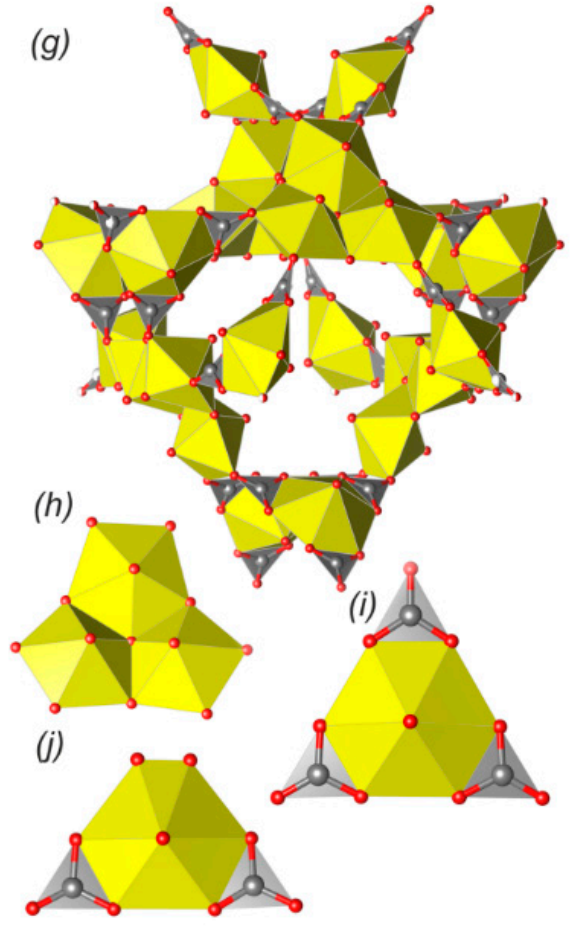

Figure 2. Finite clusters in the crystal structures of natural and synthetic uranyl carbonates and their graphical representations (see Table 1 and text for details). Legend: see Figure 1; peroxide molecule is indicated by red bond (a); see Section 3.3 for details.

Compound 36 [74], to our knowledge, is the only compound whose structure is based on the triuranyl hexacarbonate finite cluster (Figure 2e). The cluster is built by three vertexsharing in a cyclic manner uranyl hexagonal bipyramids. Each cavity at the exterior side of such a cycle is occupied by a $\mathrm{CO}_{3}$ group to form a large triangle, each side of which is built by alternating two bipyramids and three carbonate groups. The topology of the uranyl carbonate cluster (Figure $2 \mathrm{f}$ ) in the structure of 36 belongs to the $c c 0-1: 2-10$ type. The architecture of this cluster can be also described as trebling of the UTC cluster with keeping triangular motif and ideal $-6 m 2$ point group symmetry.

Probably the most remarkable structure not only among the uranyl carbonate compounds but among all known minerals, was described in ewingite (37) [75]. Ewingite is a calcium-magnesium oxo-hydroxy-hydrate uranyl carbonate natural phase, whose structure is built by 24 uranyl pentagonal and hexagonal bipyramids interlinked with each other and $\mathrm{CO}_{3}$ groups, to form nanoclusters $2.3 \mathrm{~nm}$ in diameter (Figure $2 \mathrm{~g}$ ). Three fundamental building units can be distinguished within the uranyl carbonate cluster in ewingite. These are 4 trimers of edge-sharing pentagonal bipyramids, 6 cis-isomer of the uranyl bicarbonate unit ( $c c 0-1: 2-9)$, and 6 UTC complex (Figure $2 \mathrm{~h}-\mathrm{j}$ ). Moreover, linkage of all building units occurs only through the carbonate groups. $\mathrm{Mg}$ and $\mathrm{Ca}$ ions as well as $\mathrm{H}_{2} \mathrm{O}$ molecules are arranged both inside and in between the U-bearing nanoclusters.

The crystal structures of wyartite (38) [76-79] and its dehydrated form are based on the similar layered complexes that belong to the so-called $\beta-\mathrm{U}_{3} \mathrm{O}_{8}$-sheet anion topology (Figure $3 a, b)$. Topology has the $5^{4} 4^{2} 3^{4}$ ring symbol and consists of infinite chains of edgesharing pentagons that are linked with the neighbor chains through the common vertices and separated by the chains of squares and triangles. The crystal structures of $\mathbf{3 8}$ and 38a are remarkable for being the only $\mathrm{U}(\mathrm{V})$-bearing natural phases. Pentagons are occupied by the $\mathrm{U}^{6+}$ ions, squares correspond to the irregular $\mathrm{U}^{5+} \mathrm{O}_{7}$ polyhedra, whereas triangles are 
vacant. Carbonate groups share edges with the $\mathrm{U}^{5+}$-centered polyhedra and are arranged towards the interlayer space.

(a)

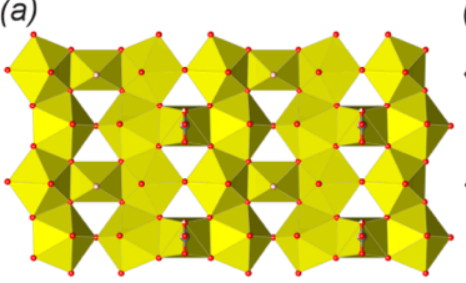

(c)

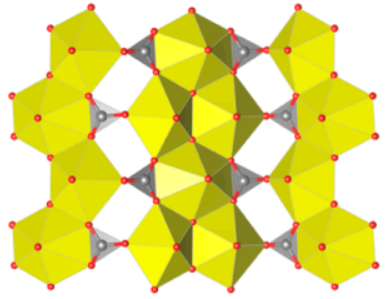

(e)

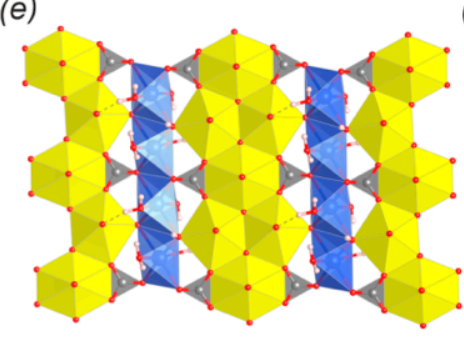

(b)

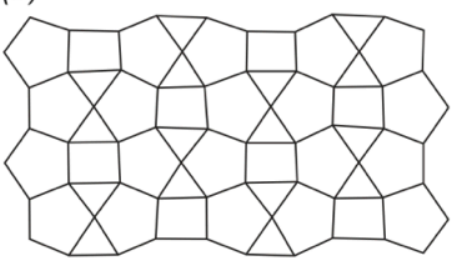

(d)

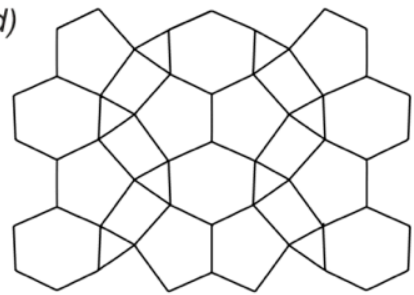

(f)

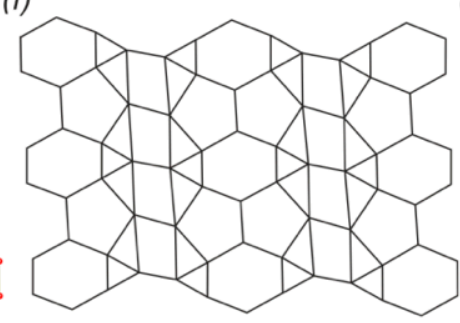

(g)

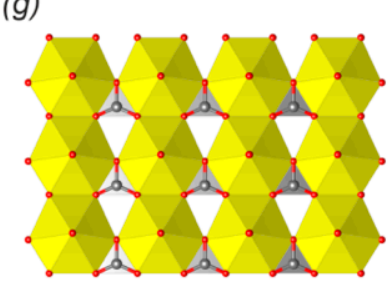

(h)

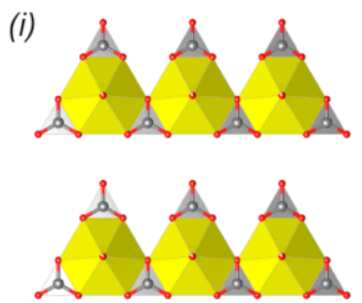

(k)

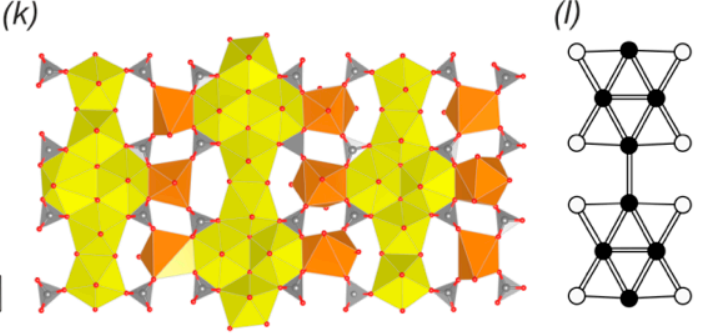

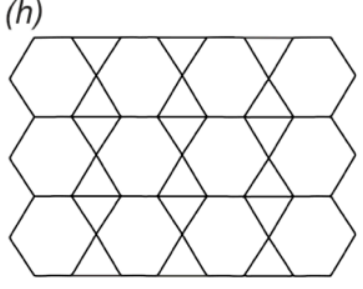

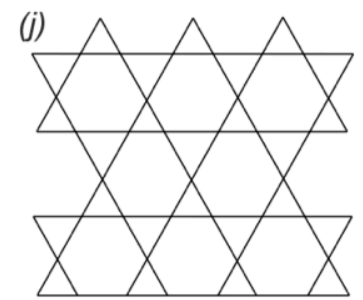

(I)

Figure 3. 2D complexes in the crystal structures of natural and synthetic uranyl carbonates and their anion topologies or graphical representation (see Table 1 and text for details). Legend: see Figure 1; Cu polyhedra $=$ blue, Nd or $\mathrm{Y}$ polyhedra = orange; see Section 3.3 for details.

The crystal structure of fontanite (39) [80,81] is based on the layered uranyl carbonate complexes, which correspond to the, so-called, phosphuranylite anion topology [137] (Figure $3 c$,d) with the $6^{1} 5^{2} 4^{2} 3^{2}$ ring symbol. The topology consists of two types of alternating infinite chains. The first type of chains is formed by edge-sharing dimers of pentagons that are interlinked by edge-sharing hexagons. The second type of chain is formed by alternating edge-sharing triangles and squares. All hexagons and pentagons are occupied by the uranyl ions, all triangles are occupied by carbonate groups, while all squares are vacant. It should be noted that phosphuranylite anion topology is very common among the U-bearing natural and synthetic phases and is represented by a wide variety of isomers, which differ in the occupancy of polygons. Thus, hexagons may be vacant, and triangles may be occupied by tetrahedral, trigonal pyramidal, or planar trigonal oxyanions (e.g., $[8,127])$.

Another anion topology that consists of hexagons, pentagons, squares and triangles with the $6^{1} 5^{2} 4^{2} 3^{6}$ ring symbol (Figure $3 \mathrm{e}, \mathrm{f}$ ) was described in the structure of roubaultite $(40)[82,83]$. Roubaultite anion topology contains the same infinite chains of edge-sharing pentagon dimers linked by edge-sharing hexagons that were observed in the phosphuranylite topology. But in the structure of $\mathbf{4 0}$, these chains are separated by infinite chains of edge-sharing squares decorated with trimers of edge-sharing triangles on the sides. All hexagons and pentagons are also occupied by the uranyl ions, as I was realized in the phosphuranylite topology. Squares are occupied by $\mathrm{Cu}$-centered slightly distorted octahedra. The middle triangle from each trimer is occupied by the carbonate group, leaving the other two triangles vacant.

The simplest uranyl carbonate, at least according to the chemical composition, rutherfordine $\left(\mathrm{UO}_{2}\right)\left(\mathrm{CO}_{3}\right)[20,84-87]$, has a layered structure. The anion topology is also rather simple; it consists of parallel chains of edge-sharing hexagons separated by hourglass 
dimers of edge-sharing triangles (Figure 3g,h). All hexagons are occupied by the uranyl ions, and one triangle from each dimer is occupied by the $\mathrm{CO}_{3}$ group, keeping the second triangle vacant. The crystal structure of sharpite (42) is also based on the layered complexes that belong to the same rutherfordine anion topology. However, the polyhedral representation appeared to be much more complex. Thus, the layer can be described as being formed by the 1D modules of rutherfordine topology. Each module represents a triple band of edge-sharing uranyl hexagonal bipyramids, a part of the triangular spaces between which are occupied by carbonate groups. These modules are arranged in the structure at approximate right angles to each other and are linked by the Ca-centered polyhedra, which are arranged on the crests of sawtooth waves (Figure 4a,b). Despite the curvature of such zigzag layers (in contrast to flat layered structure in rutherfordine) and the arrangement of Ca ions in the centers of square antiprisms, projection of such corrugated layers onto the (010) plane corresponds to the rutherfordine topology, with the equatorial arrangement of Ca polyhedra ligands having hexagon shape.
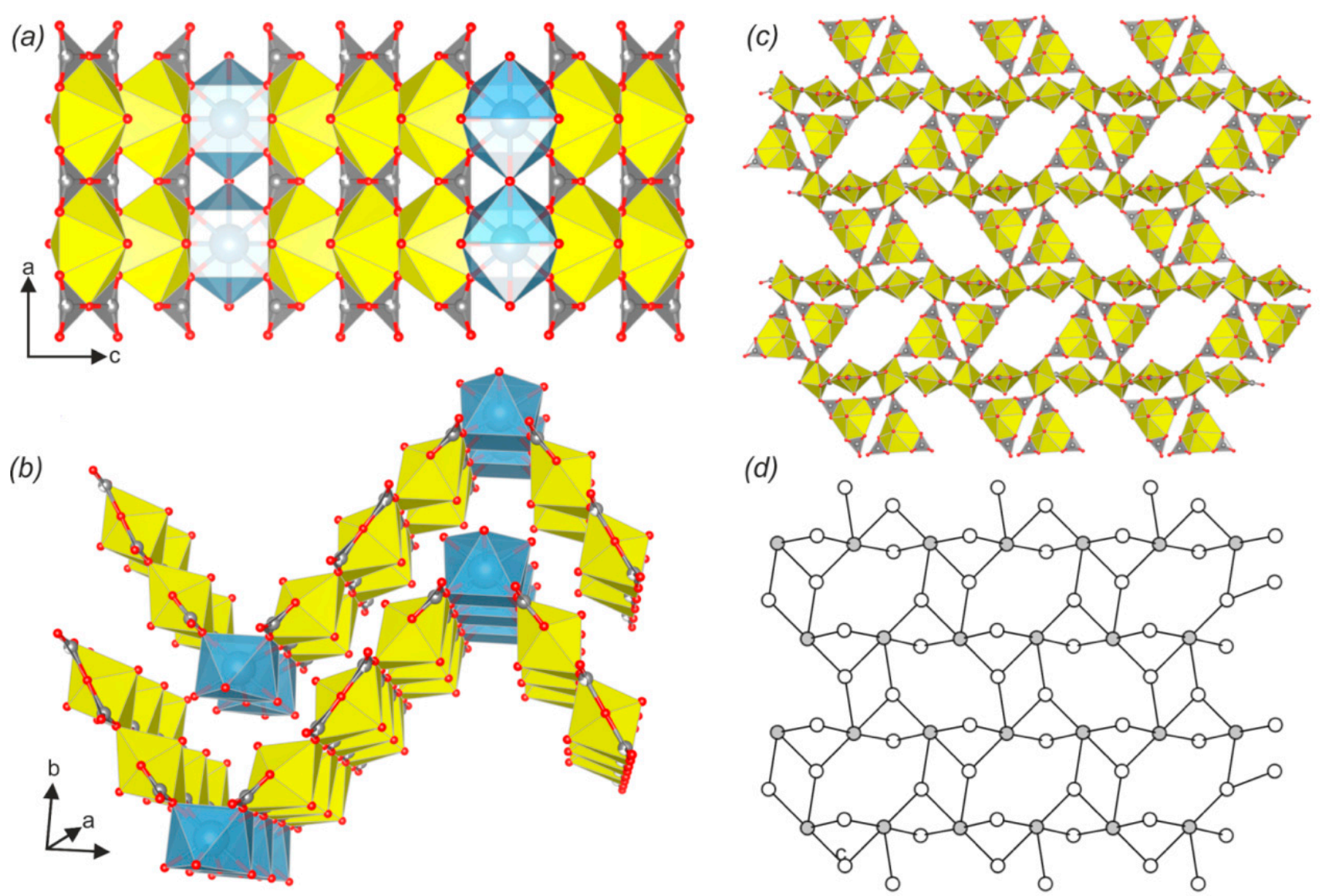

Figure 4. The crystal structures of sharpite $(\mathbf{a}, \mathbf{b})$ and meyrowitzite (c) with simplified topological representation (d). Legend: see Figure 1; Ca polyhedra = light blue.

The crystal structure of widenmannite (43) [21,91-93] is based on layered complexes, the topology of which consists of hexagons and triangles with the same $6^{1} 3^{2}$ ring symbol as was found in the structure of rutherfordine. However, the arrangement of polygons in both structures is different. Widenmannite anion topology is built by the hexagons linked by vertex-sharing to other six hexagons, while all of its six edges are shared with triangles, thus forming trihexagonal tiling, which was used by Johannes Kepler in his book [138] and is also known under the kagome pattern name. In the ideal structure of the widenmannite (Figure $3 i, j$ ) each second row of hexagonal bipyramids should be vacant, but in the real structure the disorder with partial occupancy of the $U$ sites takes place, which results in 
the occupation of all hexagons by the uranyl ions and half of the triangles oriented in the same direction are occupied by carbonate groups, keeping another half vacant.

The crystal structures of two REE-bearing minerals kamotoite-(Y) $(44)[94,95]$ and bijvoetite-(Y) $(45)[96,97]$ are based on highly remarkable and very rare layered complexes that have not been observed in any other natural or synthetic compound. The topology of the 2D complex is based on infinite chains of alternating dimers of edge-sharing uranyl hexagonal and pentagonal bipyramids (Figure $3 k, 1)$. Dimers of pentagonal bipyramids are arranged along the chain's extension, while dimers of hexagonal bipyramids are arranged perpendicularly. Each hexagonal bipyramid shares two of its oblique equatorial edges, not taking part in the linkage between $\mathrm{U}$ polyhedra, with $\mathrm{CO}_{3}$ groups. These chains are linked into the 2D structure via irregular $\mathrm{Y}^{3+}$ - or $\mathrm{Nd}^{3+}$-centered coordination polyhedra through the 6th non-shared equatorial edge from one chain and two $\mathrm{O}$ atoms of two carbonate groups from the neighbor chain. It should be noted that the resulting $\mathrm{U}$ - and REE-bearing layers are electroneutral, so the 3D structure formation is provided by the $\mathrm{H}$-bonding system, which involves $\mathrm{H}_{2} \mathrm{O}$ molecules from the coordination sphere of $R E E$ atoms and from the interlayer space.

The final to date topological type, which has been described in the structures of natural and synthetic uranyl carbonates, is observed in the structure of calcium uranyl carbonate mineral meyrowitzite (46) [98]. The structure of the layered complex is composed of UTC clusters sharing apical vertices of $\mathrm{CO}_{3}$ groups with uranyl pentagonal bipyramids (Figure 4c). This structural type, unlike the rest of the topologies described herein, is the least dense in terms of the interconnection of $U$ coordination polyhedra, and its topology will become clearer if graphical representation is used for illustration (Figure 4d). Thus, if uranyl pentagonal bipyramid is represented by grey nods, $U$ hexagonal bipyramids by white nods, and the line between nods appearing if pentagonal bipyramid shares an equatorial $\mathrm{O}$ atom with the $\mathrm{CO}_{3}$ group from the UTC cluster, the resulting graph of the complex will correspond to one of the most common $c c 1-1: 2-4$ topological type among the $\mathrm{U}(\mathrm{VI})$ bearing structures in general (e.g., $[8,127])$. Since the concept of graphical representation is violated, this description is more appropriate to use not as a direct interpretation of the topology, but as an approximate model.

\subsection{Structural and Topological Complexity}

Structural complexity measures have been implemented in several stages and the results of calculations are listed in Figures 5 and 6 and Table 2. At the first stage, the topological complexity ( $\mathrm{Tl}$ ), according to the maximal point (for finite clusters) or layer symmetry group has been determined, as these are the basic structure building units. At the second stage, the structural complexity (Sl) of the U-bearing complexes has been calculated taking into account its real symmetry. The next informational contribution comes from the stacking (LS) of finite clusters and layered complexes (if more than one complex is within the unit cell). The fourth contribution to the total structural complexity is derived by the interstitial structure (IS). The last portion of information comes from the interstitial $\mathrm{H}$ bonding system $(\mathbf{H})$. It should be noted that the $\mathrm{H}$ atoms related to the U-bearing clusters and layers were considered as a part of those complexes, but not within the contribution of the H-bonding system. Complexity parameters for the whole structure have been determined using ToposPro software [139]. 
Table 2. Structural and topological complexity parameters for the uranyl carbonate compounds.

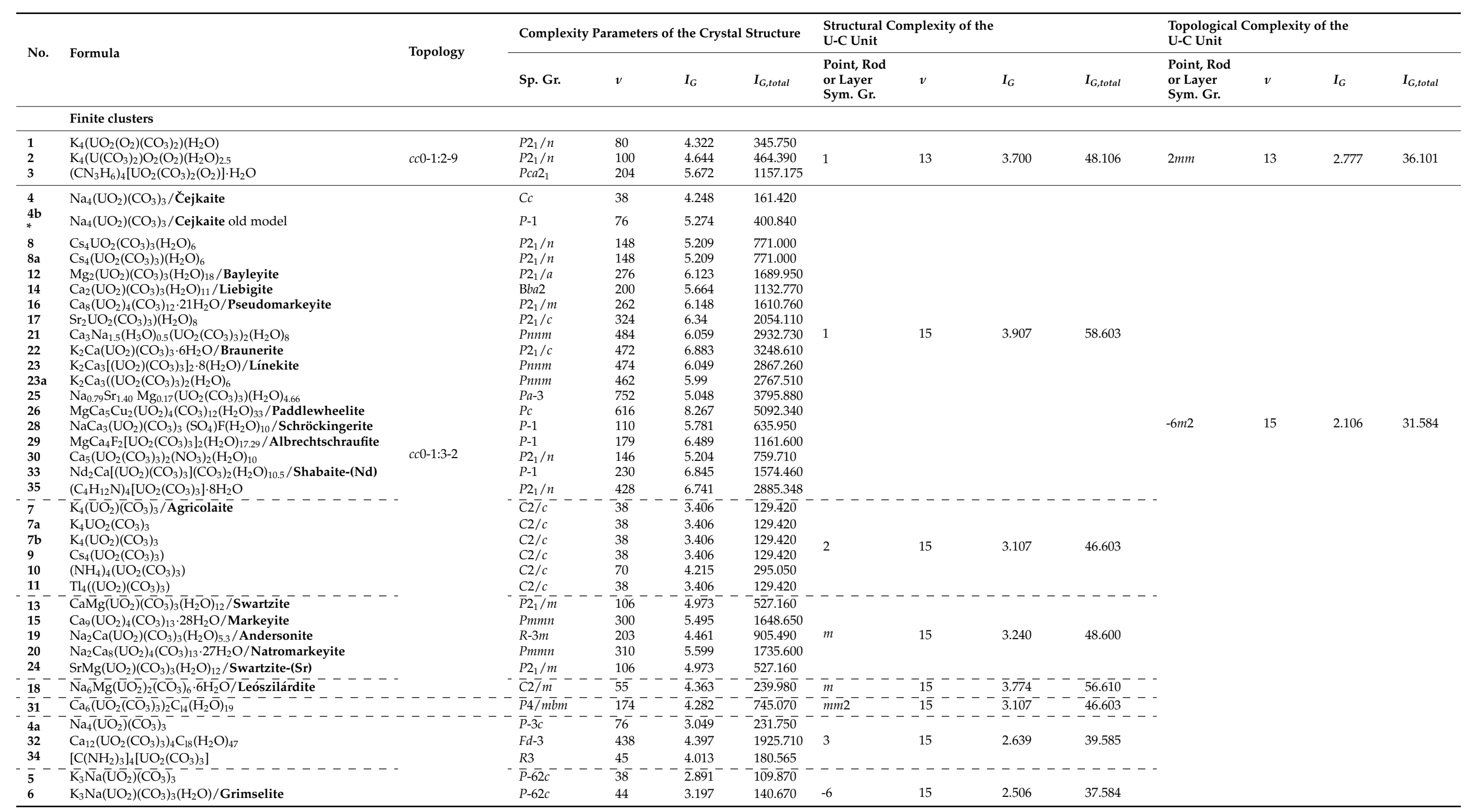


Table 2. Cont.

\begin{tabular}{|c|c|c|c|c|c|c|c|c|c|c|c|c|c|c|}
\hline \multirow{2}{*}{ No. } & \multirow{2}{*}{ Formula } & \multirow{2}{*}{ Topology } & \multicolumn{4}{|c|}{ Complexity Parameters of the Crystal Structure } & \multicolumn{4}{|c|}{$\begin{array}{l}\text { Structural Complexity of the } \\
\text { U-C Unit }\end{array}$} & \multicolumn{4}{|c|}{$\begin{array}{l}\text { Topological Complexity of the } \\
\text { U-C Unit }\end{array}$} \\
\hline & & & Sp. Gr. & $v$ & $I_{G}$ & $I_{G, \text { total }}$ & $\begin{array}{l}\text { Point, Rod } \\
\text { or Layer } \\
\text { Sym. Gr. }\end{array}$ & $v$ & $I_{G}$ & $I_{G, \text { total }}$ & $\begin{array}{l}\text { Point, Rod } \\
\text { or Layer } \\
\text { Sym. Gr. }\end{array}$ & $v$ & $I_{G}$ & $I_{G, \text { total }}$ \\
\hline $6 \mathbf{a}$ & $\mathrm{Rb}_{6} \mathrm{Na}_{2}\left(\left(\mathrm{UO}_{2}\right)\left(\mathrm{CO}_{3}\right)_{3}\right)_{2}\left(\mathrm{H}_{2} \mathrm{O}\right)$ & & $P-62 c$ & 44 & 3.197 & 140.670 & & & & & & & & \\
\hline$\overline{27}$ & $\left.\left.\overline{\mathrm{Na}} \mathrm{a}_{8} \overline{\mathrm{C}}\left(\overline{\mathrm{U} \mathrm{O}_{2}}\right)\left(\overline{\mathrm{C}} \overline{\mathrm{C}}_{3}\right)_{3}\right](\overline{\mathrm{SO}})_{4}\right)_{2} \cdot 3 \overline{\mathrm{H}}_{2} \overline{\mathrm{O}} / \overline{\mathrm{J}}$ ežekite & & $\bar{P}-\overline{62} \bar{m}$ & ${ }^{-} 42^{-}$ & $\overline{3} . \overline{4} 8^{-}$ & $-{ }^{-} 1 \overline{4} 6 . \overline{9} 3 \overline{0}$ & $-6 \bar{m} 2^{-}$ & $-1 \overline{5}$ & $\overline{2} \cdot \overline{0} 6^{-}$ & ${ }^{-} 3 \overline{1} .5 \overline{8} 4^{-}$ & & & & \\
\hline \multirow[t]{2}{*}{36} & {$\left[\mathrm{C}\left(\mathrm{NH}_{2}\right)_{3}\right]_{6}\left[\left(\mathrm{UO}_{2}\right)_{3}\left(\mathrm{CO}_{3}\right)_{6}\right]\left(\mathrm{H}_{2} \mathrm{O}\right)_{6.5}$} & $c c 0-1: 2-10$ & $P-1$ & 225 & 6.818 & 1534.100 & 1 & 33 & 5.044 & 166.452 & $-6 m 2$ & 33 & 2.914 & 96.162 \\
\hline & Nanoclusters & & & & & & & & & & & & & \\
\hline \multirow[t]{3}{*}{37} & $\mathrm{Mg}_{8} \mathrm{Ca}_{8}\left(\mathrm{UO}_{2}\right)_{24}\left(\mathrm{CO}_{3}\right)_{30} \mathrm{O}_{4}(\mathrm{OH})_{12}\left(\mathrm{H}_{2} \mathrm{O}\right)_{138} /$ Ewingite & & $I 4_{1} /$ acd & 2508 & 7.311 & $18,335.988$ & -4 & 220 & 5.781 & 1271.820 & -4 & 220 & 5.781 & 1271.820 \\
\hline & Layers & & & & & & & & & & & & & \\
\hline & $5^{4} 4^{2} 3^{4}\left(\beta-U_{3} O_{8}\right)$ & & & & & & & & & & & & & \\
\hline 38 & CaU $\left(\mathrm{UO}_{2}\right)_{2}\left(\mathrm{CO}_{3}\right) \mathrm{O}_{4}(\mathrm{OH})\left(\mathrm{H}_{2} \mathrm{O}\right)_{7} /$ Wyartite & & $P 2_{1} 2_{1} 2_{1}$ & 156 & 5.285 & 824.52 & $p 2_{1}$ & 40 & 4.322 & 172.880 & $n=. m n$ & 40 & 3.822 & 152.880 \\
\hline \multirow[t]{2}{*}{ 38a } & $\mathrm{Ca}\left(\mathrm{U}\left(\mathrm{UO}_{2}\right)_{2}\left(\mathrm{CO}_{3}\right)_{0.7} \mathrm{O}_{4}(\mathrm{OH})_{1.6}\right)\left(\mathrm{H}_{2} \mathrm{O}\right)_{1.63}$ & & Pmon & 84 & 3.821 & 320.964 & $p 2_{1} m n$ & 36 & 3.614 & 130.103 & $p 2{ }_{1} m n$ & 36 & 3.614 & 130.103 \\
\hline & $6^{1} 5^{2} 4^{2} 3^{2}$ (phosphuranylite) & & & & & & & & & & & & & \\
\hline \multirow[t]{2}{*}{39} & $\mathrm{Ca}\left(\mathrm{UO}_{2}\right)_{3}\left(\mathrm{CO}_{3}\right)_{2} \mathrm{O}_{2}\left(\mathrm{H}_{2} \mathrm{O}\right)_{6} /$ Fontanite & & $P 2_{1} / n$ & 152 & 5.248 & 797.685 & $p 11 n$ & 38 & 4.248 & 161.424 & $\mathrm{cmmm}$ & 19 & 2.880 & 54.720 \\
\hline & $6^{1} 5^{2} 4^{2} 3^{6}$ (roubaultite) & & & & & & & & & & & & & \\
\hline \multirow[t]{2}{*}{40} & $\mathrm{Cu}_{2}\left(\mathrm{UO}_{2}\right)_{3}\left(\mathrm{CO}_{3}\right)_{2} \mathrm{O}_{2}(\mathrm{OH})_{2}\left(\mathrm{H}_{2} \mathrm{O}\right)_{4} /$ Roubaultite & & $P-1$ & 37 & 4.236 & 156.750 & $\mathrm{p}-1$ & 23 & 3.567 & 82.042 & pammm & 23 & 1.837 & 42.239 \\
\hline & Finite clusters & & & & & & & & & & & & & \\
\hline 41 & $\left.\mathrm{UO}_{2}\right)\left(\mathrm{CO}_{3}\right) /$ Rutherfordine & & $\operatorname{Imm} 2$ & 7 & 2.236 & 15.651 & $p 2 m m$ & 7 & 2.236 & 15.651 & $p 2 m m$ & 7 & 2.236 & 15.651 \\
\hline \multirow[t]{2}{*}{$\overline{42}$} & 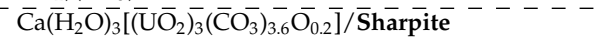 & & $\overline{\mathrm{Cm}} \overline{\mathrm{cm}}-\overline{-}$ & $\overline{7} 2$ & $-\overline{3.837}$ & $\overline{276} . \overline{235}{ }^{-}$ & $\overline{\mathrm{p} 2} / m \overline{1} 1$ & $24^{-}$ & $\overline{3.335}$ & $\overline{80.040}$ & $\overline{\mathrm{p}_{\mathrm{b}}} \overline{m m} \bar{m}$ & $\overline{2} 4^{-}$ & $-\overline{3.168}$ & $\overline{7} \overline{6} .0 \overline{32}$ \\
\hline & $6^{1} 3^{2}-I I$ (widenmannite) & & & & & & & & & & & & & \\
\hline \multirow[t]{2}{*}{43} & $\mathrm{~Pb}_{2}\left[\left(\mathrm{UO}_{2}\right)\left(\mathrm{CO}_{3}\right)_{2}\right]$ & & Pmmn & 34 & 3.382 & 114.974 & $\mathrm{p} 2 m m$ & 11 & 2.914 & 32.054 & $\mathrm{p}_{\mathrm{b}} 2 m m$ & 11 & 2.914 & 32.054 \\
\hline & Layers of miscellaneous topology & & & & & & & & & & & & & \\
\hline \multirow{2}{*}{$\begin{array}{l}44 \\
45\end{array}$} & $\mathrm{Y}_{2}\left(\mathrm{UO}_{2}\right)_{4}\left(\mathrm{CO}_{3}\right)_{3} \mathrm{O}_{4} \cdot 14 \mathrm{H}_{2} \mathrm{O} /$ Kamotoite-( $\left.\mathrm{Y}\right)$ & & $P 2_{1} / n$ & 282 & 6.147 & 1733.353 & $\mathrm{p} 11 a$ & 64 & 5.000 & 320.000 & \multirow[t]{2}{*}{$\mathrm{p}_{\mathrm{b}} m m m$} & 32 & 3.250 & 104.000 \\
\hline & {$\left[\left(\mathrm{Y}_{4.22} \mathrm{Nd}_{3.78}\right)\left(\mathrm{H}_{2} \mathrm{O}\right)_{25}\left(\mathrm{UO}_{2}\right)_{16} \mathrm{O}_{8}(\mathrm{OH})_{8}\left(\mathrm{CO}_{3}\right)_{16}\right]\left(\mathrm{H}_{2} \mathrm{O}\right)_{1}$} & ijvoetite- & $B 2_{1}$ & 522 & 8.028 & 4190.567 & $\mathrm{p} 1$ & 68 & 6.087 & 413.916 & & 34 & 3.382 & 114.988 \\
\hline$\overline{46}^{-}$ & 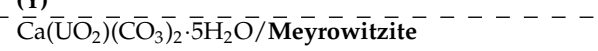 & & $-\overline{P 2}_{1} \bar{\gamma}^{-}$ & $-\overline{3} 2 \overline{0}$ & $-\overline{6.322}$ & $\overline{2023.01 \overline{7}}$ & $-\bar{p} 2_{1} / b$ & $\overline{1} \overline{2}$ & $\overline{5.044}$ & ${ }^{-} \overline{6} \overline{5} . \overline{80} 8^{-}$ & $\overline{p 2} \overline{1} b$ & $\overline{1} 3 \overline{2}$ & $-\overline{5.044}$ & $-\overline{6} \overline{65 . \overline{8} 0 \overline{8}}$ \\
\hline
\end{tabular}

* -although the old model of čejkaite is erroneous from the structural point of view, it was decided to keep complexity calculations for it due to presence of structural data in the database. 

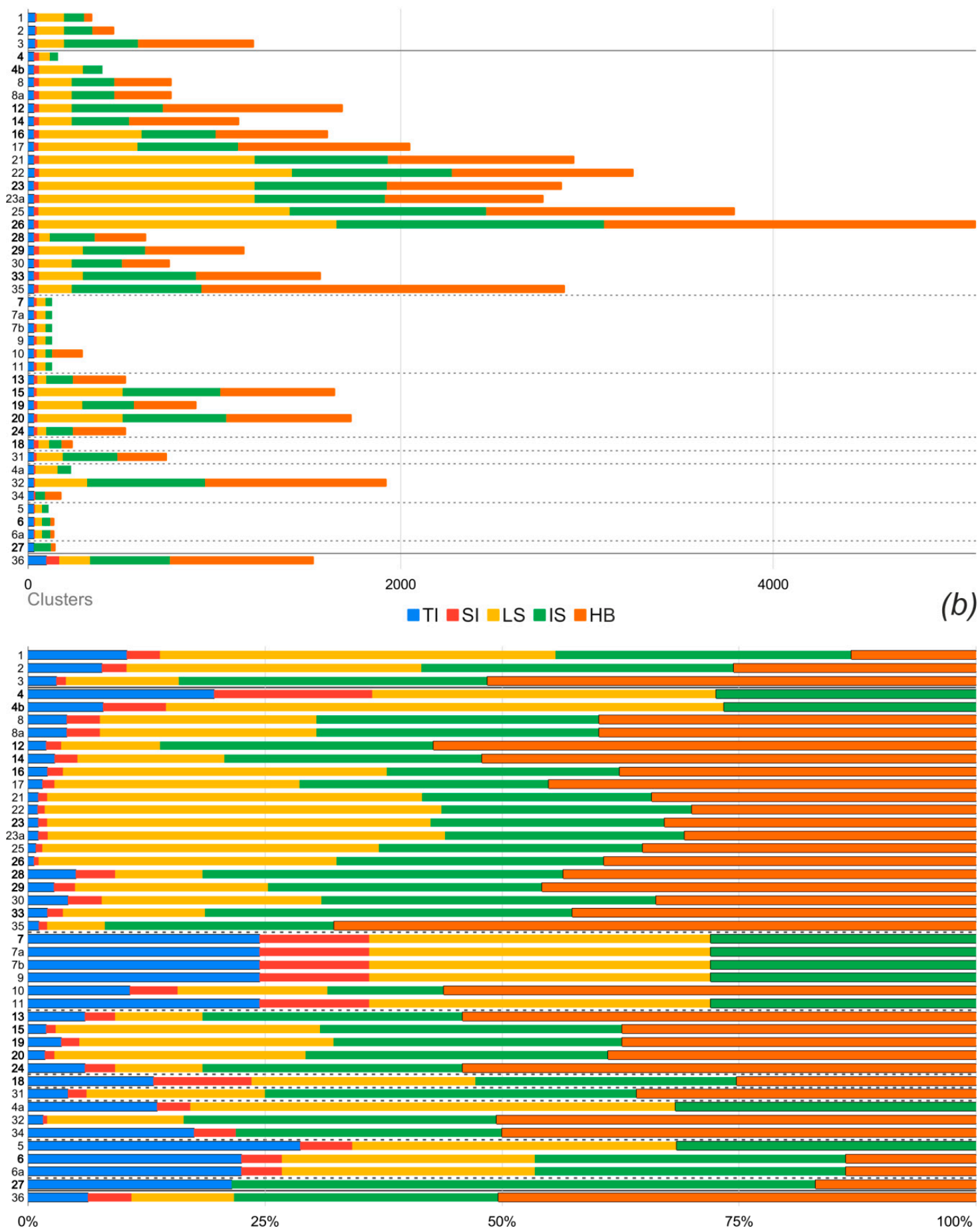

Figure 5. Ladder diagrams showing contributions to structural complexity (bits per unit cell) (a) and normalized contributions (in \%) (b) for the structures based on uranyl carbonate finite clusters. Legend: TI = topological information; $\mathrm{SI}=$ structural information; LS = layer stacking; IS = interstitial structure; HB = hydrogen bonding. See Table 2 and text for details. 
Layers

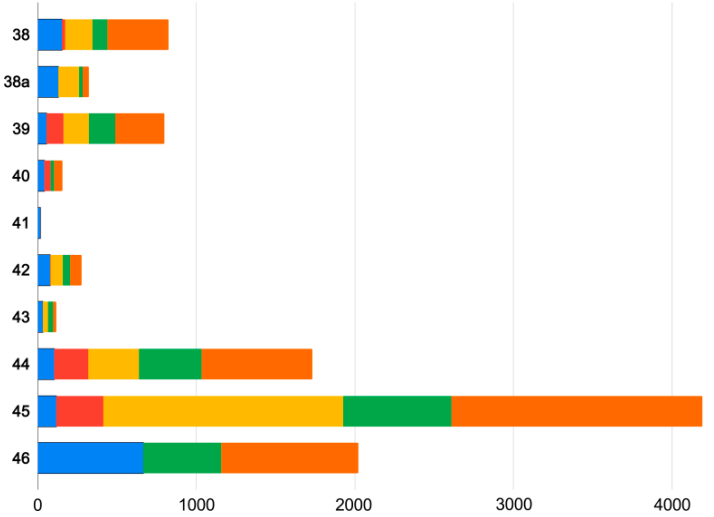

(a)

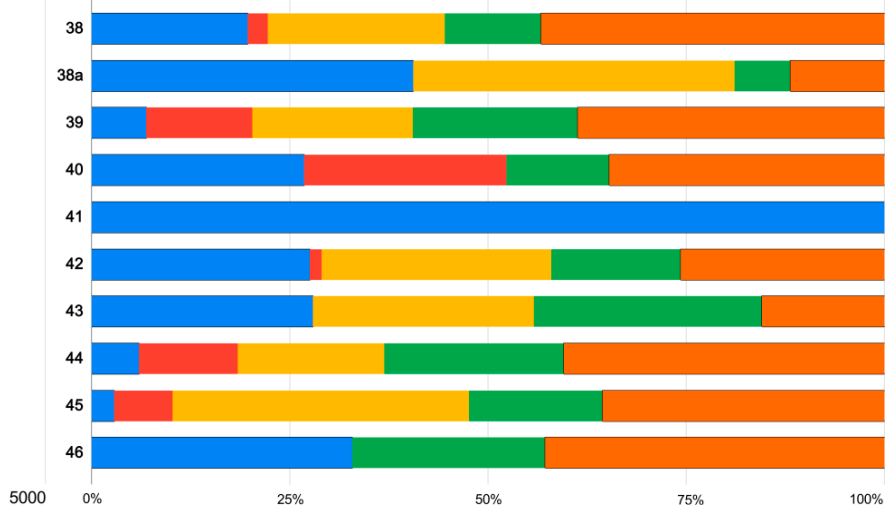

Figure 6. Ladder diagrams showing contributions to structural complexity (bits per unit cell) (a) and normalized contributions (in \%) (b) for the structures based on uranyl carbonate layers. Legend: see Figure 5. See Table 2 and text for details.

\section{Discussion}

All three synthetic compounds, whose structures are based on finite clusters of the cc0-1:2-9 topological type (Table 2), demonstrate low real (structural) symmetry of the uranyl bicarbonate cluster that corresponds to the point symmetry group 1 . However, the topological symmetry of the cluster is much higher and is described by the orthorhombic point symmetry group $2 \mathrm{~mm}$ (Figure $7 \mathrm{a}$ ). It should be noted that all three compounds have similar $Z=4$, and thus have equal contribution not only of TI and SI domains, but also from the LS. Complexity of these compounds largely depends on the nature of the interstitial component and hydration state. Substitution of inorganic $\mathrm{K}^{+}$ions (in $\mathbf{1}$ and $\mathbf{2}$ ) by the guanidinium cations (in 3) transfer compound in terms of complexity from intermediate to very complex group.

(a)

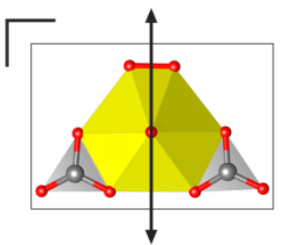

(b)

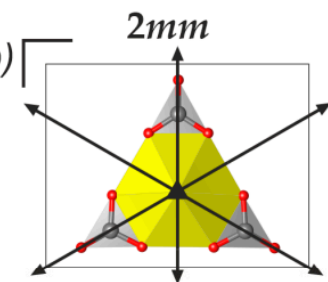

(c)

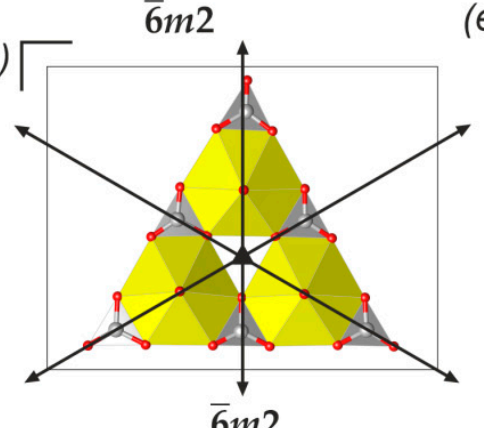

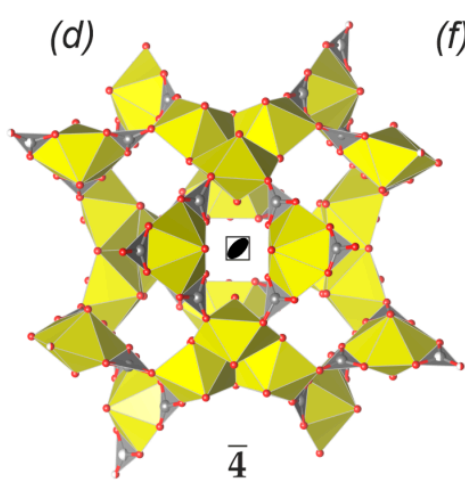

$\overline{4}$

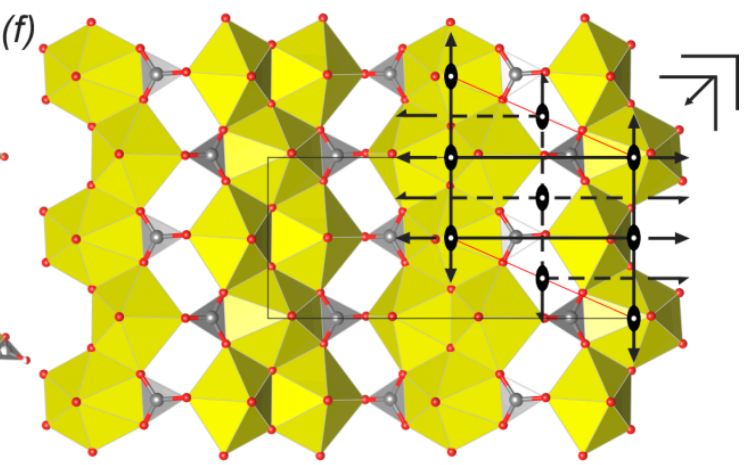

cmmm (e)

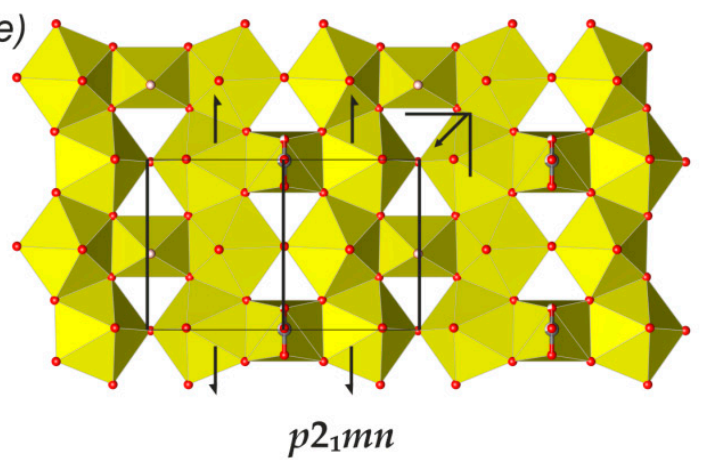

(g)

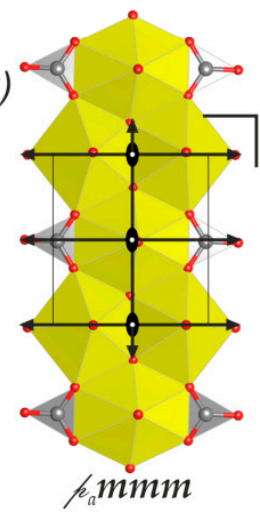

Figure 7. Uranyl carbonate complexes and their highest (topological) symmetry groups. Legend: see Figure 1. See text for details. 
Topological symmetry of the uranyl tricarbonate cluster (cc0-1:3-2 type) is described by the $-6 m 2$ point group (Figure $7 \mathrm{~b}$ ), and mineral ježekite, 27 [62], and is the only compound whose topological symmetry preserves in a real structure. Another six compounds $\mathbf{4 a}, \mathbf{5}$, 6a, 32, 34, including mineral grimselite, 6 [20-23], have rather high structural symmetry of the UTC: trigonal point group $3(4 \mathbf{a}, 32,34)$ or hexagonal point group $-6(5,6,6 \mathbf{a})$, which results in a slight increase of SI contribution after TI portion. It should be noted that the cubic symmetry of the whole structures of $\mathbf{4 a}$ and $\mathbf{3 2}$ is higher than the topological symmetry of the cluster, which demonstrates that interstitial cations and $\mathrm{H}_{2} \mathrm{O}$ molecules can act as symmetry breaking agents, and not only symmetry reducing. It is of interest that all six compounds that have the structural symmetry of the UTC equal to point group $m$ are minerals. Moreover, compounds with structural symmetry of the UTC equal to point group 2 are also represented by mineral agricolaite, 7 [25], and its synthetic analogs. Thus, all compounds with monoclinic structural symmetry of the uranyl tricarbonate clusters are related to natural phases. Nearly half of all compounds, whose structures are based on the UTC have the lowest structural symmetry of the cluster, described by the triclinic non-centrosymmetric point group 1, and the distribution between minerals and synthetic compounds here is almost uniform. Second, the most complex compound among the uranyl carbonates is paddlewheelite, 26 [61], whose structure is also based on the UTC units, and information content is 8.267 bits/atom and 5092.340 bits/cell. It should be however mentioned that paddlewheelite has one of the largest information contents per atom among the uranyl carbonate compounds, which is achieved due to a large amount of interstitial cations and $\mathrm{H}_{2} \mathrm{O}$ molecules along with the rather high density of their framework arrangement.

The crystal structure of synthetic compound 36 [74] is based on the large triangular triuranyl hexacarbonate clusters of $c c 0-1: 2-10$ topological type, which has the same topological symmetry $-6 m 2$ as UTC cluster (Figure 7c). But at the same time the structural symmetry of this cluster is the lowest and corresponds to the triclinic point group 1. The unit cell of 36 contains two triuranyl hexacarbonate clusters but their contribution (TI + SI + LS) is comparable with a contribution of four UTC clusters of the same structural symmetry.

Ewingite, 37 [75], is a mineral with the most complex crystal structure known nowadays (Table 2; Figure 7d). According to the structure reported by Olds and coauthors [75], the structural model of ewingite contains $12,684.860 \mathrm{bits} / \mathrm{cell}$, but considering an additional estimated amount of $\mathrm{H}_{2} \mathrm{O}$ molecules and respective $\mathrm{H}$ atoms in complexity calculations, the total information amount will be presumably equal to c.a. 23,000 bits/cell. Our attempts to get rid of disordered sites and to assign $\mathrm{H}$ atoms to $\mathrm{H}_{2} \mathrm{O}$ molecules and $\mathrm{OH}$ groups resulted in the value of 18,335.988 bits/cell. However, it should be kept in mind that the imperfect quality of measured crystals didn't allow to assign all disordered sites of $\mathrm{H}_{2} \mathrm{O}$ molecules in the structural model. Thus, to reach the value of 23,000 bits/cell, an additional 12 fully occupied $\mathrm{H}_{2} \mathrm{O}$ sites (48 molecules per formula unit) should appear in the structure, which is somewhat doubtful. Most likely, one could expect the structural complexity of ewingite to be in the range of 19,500-21,500 bits/cell, depending on the variable hydration state. The contribution of TI and SI into the total information content is the smallest (6.9\%), stacking is giving another $20.8 \%$, while the contribution of interstitial structure $(24.7 \%)$ and H-bonding system $(47.6 \%)$ gives nearly $\frac{3}{4}(72.3 \%)$ of the total complexity of ewingite crystal structure. Complexity parameters for ewingite are listed in Table 2, but omitted from Figure 5 for clarity.

The crystal structures of wyartite, 38 [76-78], and its dehydrated analog 38a [79] are based on the layers of $\beta-\mathrm{U}_{3} \mathrm{O}_{8}$ anion topology, whose topological symmetry is described by the orthorhombic layer symmetry group $p 2_{1} m n$ (Figure 7e). The presence of a significant amount of $\mathrm{H}_{2} \mathrm{O}$ molecules in the coordination sphere of interstitial cations reduces the layer's structural symmetry in wyartite, while the release of $\mathrm{H}_{2} \mathrm{O}$ and subsequent linkage of U-bearing layers directly through the Ca-centered polyhedra keeps the topological symmetry and breaks the symmetry of the whole structure of 38a, which results in a decrease of information content by 2.5 times in comparison with the structure of natural compound 38 . 
U-bearing layers with phosphuranylite anion topology play an important role in the mineralogy of uranyl selenites as has been recently shown [127]. There is only one uranyl carbonate, mineral fontanite, 39 [80,81], whose structure is based on the layers of this topological type (Figure 7f). However, the structure of uranyl carbonate layers in fontanite differs from that in uranyl selenite minerals and synthetic compounds (Figure 8). Pyramidal selenite groups with lone electron pairs make chains of edge-sharing Ur polyhedra arranged as stepped [127] or zig-zag layers (Figure 8c). In the structure of marthozite, as an example of zig-zag layers, equatorial planes of $U r$ bipyramids are arranged parallel to the mean plane of the layer. In the structure of fontanite, uranyl carbonate layer has also a zig-zag manner, but equatorial planes of $U r$ bipyramids make an angle of c.a. $135^{\circ}$ at the linkage with the neighbor chain of edge-sharing $U r$ polyhedra. Topological symmetry of uranyl carbonate layer $(\mathrm{cmmm})$ is higher than that in uranyl selenite marthozite ( $\mathrm{pmmm} \mathrm{[127])}$ because of the flat carbonate groups in comparison to selenite pyramids, but the structural symmetry $(p 11 n)$ and complexity parameters of U-bearing layers in fontanite are the same as were reported for marthozite [127].

(a)
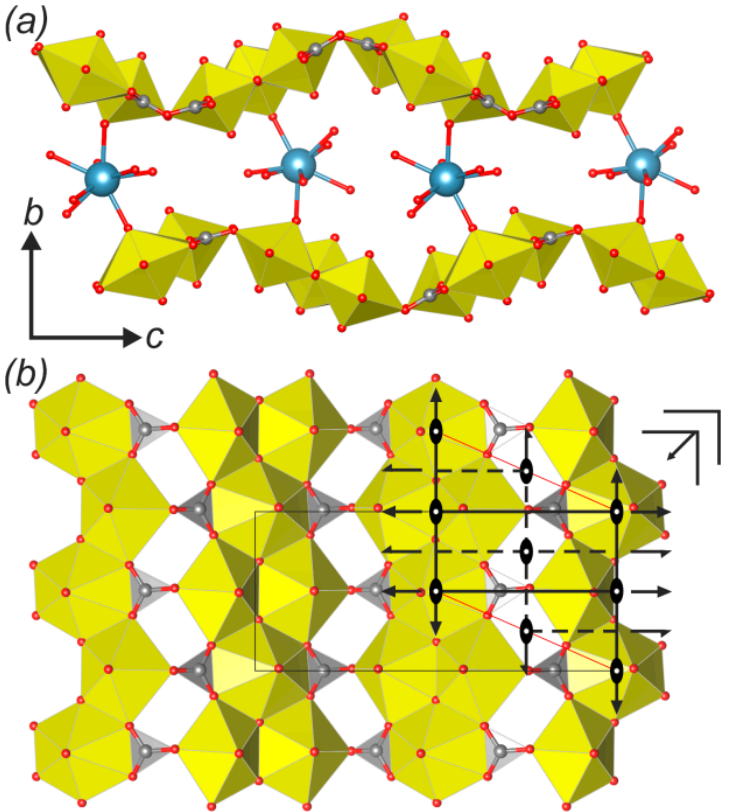

cmmm

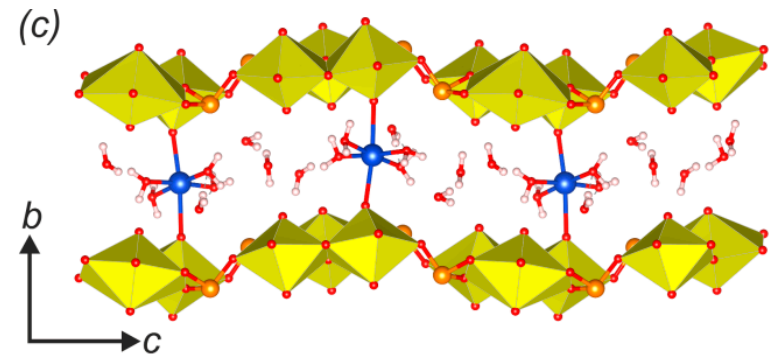

(d)

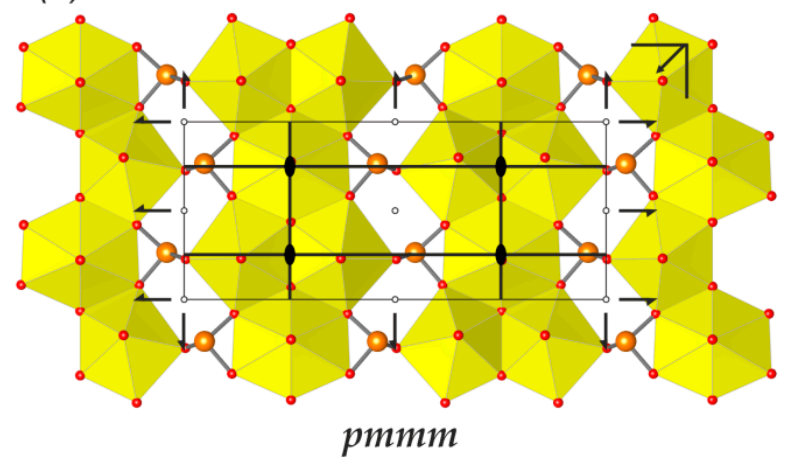

Figure 8. The crystal structures of fontanite (a) and marthozite (c), uranyl carbonate (b) and uranyl selenite (d) layers of phosphuranylite topology in their structures, and respective topological symmetry groups. Legend: see Figures 1 and 7.

The crystal structure of rutherfordine, 41 [20,84-87], is the simplest among natural and synthetic uranyl carbonates. It is also of special interest because the total amount of information is equal to the topological symmetry contribution (Table 2; Figure 9a). It happens because there is no interstitial structure in rutherfordine, and the body-centered cell is reduced to a single layer.

U-bearing layers of rutherfordine anion topology are also found in the structure of sharpite, 42 [88-90]. However, from a structural point of view, this topology is obtained from uranyl carbonate chains linked by the Ca-centered polyhedra, whose topological symmetry is described by the $\mathrm{p}_{\mathrm{b}} \mathrm{mmm}$ rod symmetry group (Figure $9 \mathrm{~b}$ ). A similar situation is observed in the structure of roubaultite, 40 [82,83], in which the U-bearing layer can be described in terms of anion topology, but actually is built by the chains of $\mathrm{p}_{\mathrm{a}} \mathrm{mmm}$ topological symmetry (Figure 7g) similar to those found in phosphuranylite topology, and linked not directly to each other, but through $\mathrm{Cu}$-centered octahedra. Similarly, and as it was described in the Section 3.3, each second row of hexagonal bipyramids in the structure 
of widenmannite, 43 [93] should ideally be vacant, so the structure can be described as built by chains of the $\mathrm{p}_{\mathrm{b}} 2 \mathrm{~mm}$ rod symmetry group (Figure $9 \mathrm{c}$ ).

Bijvoetite-(Y), $45[96,97]$, is the most complex compound among the layered uranyl carbonates (Table 2) with a structure based on the uranyl carbonate chains (Figure 9d) linked through the REE-centered polyhedra. While meyrowitzite, 46 [98], has the largest TI and SI complexity parameters (Table 2; Figure 9e) among the uranyl carbonate compounds.

(a)

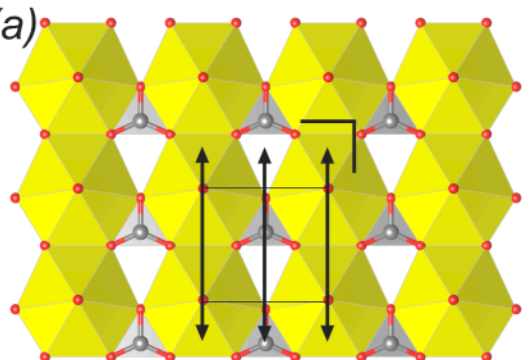

(b)

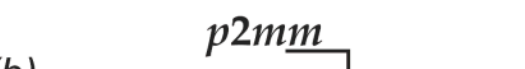

(d)

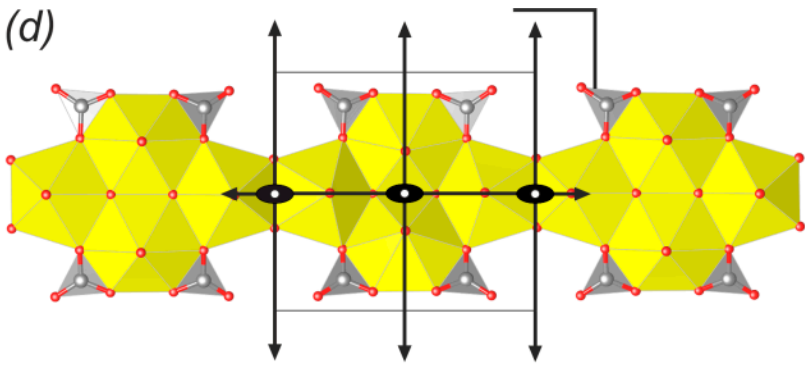

fommm
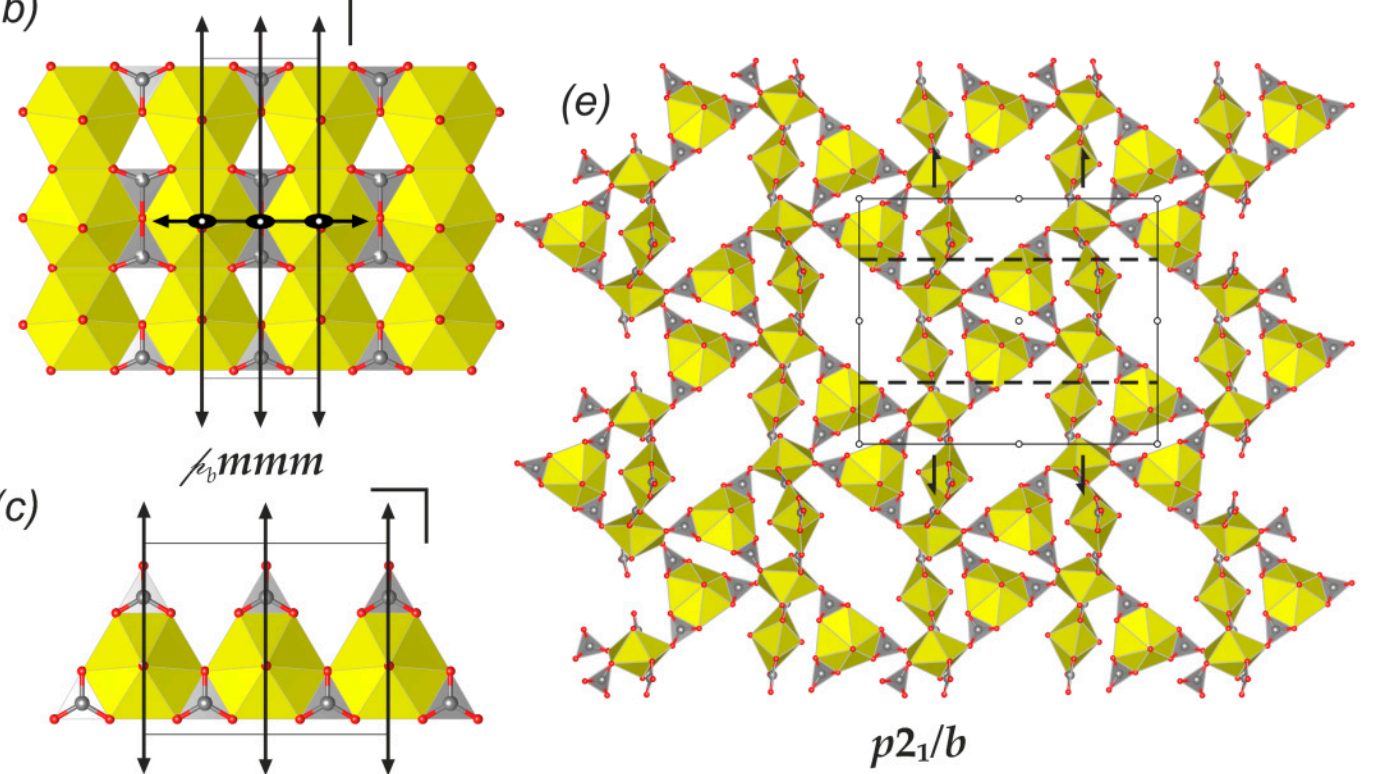

(c)

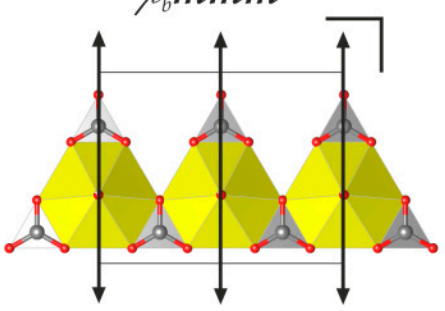

$142 m m$

Figure 9. Uranyl carbonate complexes and their topological symmetry groups. Legend: see Figure 7. See text for details.

\section{Conclusions}

Comparison of crystal-chemical characteristics of isotypic natural and synthetic compounds can give an answer to the environmental conditions of mineral growth. For instance, the majority of synthetic analogs of minerals were obtained from aqueous solutions at room temperature. This observation allows us to assume that the formation of natural uranyl carbonates does not need any specific environmental conditions (increased P or T), which was recently suggested for uranyl selenites [127] and uranyl sulfates [126].

Structural and topological complexity calculations demonstrate that information content, in general, is usually higher for minerals than for synthetic compounds of similar or close chemical composition, which is likely to point to the higher stability and preferred architectures of natural compounds. However, one interesting feature that was not observed during recent complexity studies of uranyl selenite and sulfate compounds should be noted. A significant portion of compounds have the real symmetry of the structure higher than the structural symmetry of the uranyl carbonate complex. It should be also kept in mind that uranyl carbonate substructural units have average topographical diversity, and mainly include the finite clusters with rigid, edge-sharing manner, of coordination polyhedra 
polymerization. Thus the structural architecture of uranyl carbonates is largely governed by the interstitial cations and the hydration state of the compounds, while uranyl carbonate complexes play the role of flexible structural skeleton or stone aggregates in concrete.

Author Contributions: Conceptualization, V.V.G. and J.P.; Methodology, V.V.G., S.A.K., I.V.K. and J.P.; Investigation, V.V.G., S.A.K., I.V.K. and J.P.; Writing-Original Draft Preparation, V.V.G., S.A.K., I.V.K. and J.P.; Writing-Review \& Editing, V.V.G. and J.P.; Visualization, V.V.G. and I.V.K. All authors have read and agreed to the published version of the manuscript.

Funding: This research was funded by the Russian Science Foundation (grant 18-17-00018 to V.V.G. and I.V.K.), by the President of Russian Federation grant to leading scientific schools (grant NSh2526.2020.5 to S.A.K.) and through the Czech Science foundation (project 20-11949S to J.P.).

Acknowledgments: We are grateful to reviewers for useful comments.

Conflicts of Interest: The authors declare no conflict of interest.

\section{References}

1. Alwan, A.K.; Williams, P.A. The aqueous chemistry of uranium minerals. Part 2. Minerals of the liebigite group. Mineral. Mag. 1980, 43, 665-667. [CrossRef]

2. Clark, D.L.; Hobart, D.E.; Neu, M.P. Actinide carbonate complexes and their importance in actinide environmental chemistry. Chem. Rev. 1995, 95, 25-48. [CrossRef]

3. Plášil, J. Oxidation-hydration weathering of uraninite: The current state-of-knowledge. J. Geosci. 2014, 59, 99-114. [CrossRef]

4. Stefaniak, E.A.; Alsecz, A.; Frost, R.; Mathe, Z.; Sajo, I.E.; Torok, S.; Worobiec, A.; Van Grieken, R. Combined SEM/EDX and micro-Raman spectroscopy analysis of uranium minerals from a former uranium mine. J. Hazard Mater. $2009,168,416-423$. [CrossRef] [PubMed]

5. Driscoll, R.J.P.; Wolverson, D.; Mitchels, J.M.; Skelton, J.M.; Parker, S.C. A Raman spectroscopic study of uranyl minerals from Cornwall, UK. RSC Adv. 2014, 4, 59137-59149. [CrossRef]

6. Teterin, Y.A.; Baev, A.S.; Bogatov, S.A. X-ray photoelectron study of samples containing reactor fuel from "lava" and products growing on it which formed at Chernobyl NPP due to the accident. J. Electron Spectrosc. Relat. Phenom. 1994, 68, 685-694. [CrossRef]

7. Burakov, B.E.; Strykanova, E.E.; Anderson, E. Secondary uranium minerals on the surface of Chernobyl "Lava”. Mat. Res. Soc. Symp. Proc. 1996, 465, 1309-1311. [CrossRef]

8. Lussier, A.J.; Lopez, R.A.K.; Burns, P.C. A revised and expanded structure hierarchy of natural and synthetic hexavalent uranium compounds. Can. Mineral. 2016, 54, 177-283. [CrossRef]

9. Gurzhiy, V.V.; Plášil, J. Structural complexity of natural uranyl sulfates. Acta Crystallogr. 2019, B75, 39-48. [CrossRef]

10. Lafuente, B.; Downs, R.T.; Yang, H.; Stone, N. The power of databases: The RRUFF project. In Highlights in Mineralogical Crystallography; Armbruster, T., Danisi, R.M., Eds.; De Gruyter: Berlin, Germany, 2015; pp. 1-30.

11. Goff, G.S.; Brodnax, L.F.; Cisneros, M.R.; Peper, S.M.; Field, S.E.; Scott, B.L.; Runde, W.H. First identification and thermodynamic characterization of the ternary $\mathrm{U}(\mathrm{VI})$ species, $\mathrm{UO}_{2}\left(\mathrm{O}_{2}\right)\left(\mathrm{CO}_{3}\right) 2(4-)$, in $\mathrm{UO}_{2}-\mathrm{H}_{2} \mathrm{O}_{2}-\mathrm{K}_{2} \mathrm{CO}_{3}$ solutions. Inorg. Chem. 2008, 47, 1984-1990. [CrossRef]

12. Zehnder, R.; Peper, S.; Brian, L.; Runde, S.; Runde, W. Tetrapotassium dicarbonatodioxoperoxouranium(VI) 2.5-hydrate, $\mathrm{K}_{4}\left[\mathrm{U}\left(\mathrm{CO}_{3}\right)_{2} \mathrm{O}_{2}\left(\mathrm{O}_{2}\right)\right] \cdot 2.5 \mathrm{H}_{2} \mathrm{O}$. Acta Crystallogr. 2005, C61, 3-5.

13. Mikhailov, Y.N.; Lobanova, G.M.; Shchelokov, R.N. X-ray structural study of the guanidinium uranyl-peroxo-dicarbonate hydrate $\left(\mathrm{CN}_{3} \mathrm{H}_{6}\right)_{4} \mathrm{UO}_{2} \mathrm{O}_{2}\left(\mathrm{CO}_{3}\right)_{2} \cdot \mathrm{H}_{2} \mathrm{O}$. Zh. Neorg. Khim. 1981, 26, 718-722.

14. Plášil, J.; Fejfarová, K.; Dušek, M.; Škoda, R.; Rohlíček, J. Actinides in Geology, Energy, and the Environment. Revision of the symmetry and the crystal structure of čejkaite, $\mathrm{Na}_{4}\left(\mathrm{UO}_{2}\right)\left(\mathrm{CO}_{3}\right)_{3}$. Am. Mineral. 2013, 98, 549-553. [CrossRef]

15. Li, Y.; Krivovichev, S.V.; Burns, P.C. The crystal structure of $\mathrm{Na}_{4}\left(\mathrm{UO}_{2}\right)\left(\mathrm{CO}_{3}\right)_{3}$ and its relationship to schröckingerite. Mineral. Mag. 2001, 65, 297-304. [CrossRef]

16. Císařová, I.; Skála, R.; Ondruš, P.; Drábek, M. Trigonal $\mathrm{Na}_{4}\left[\mathrm{UO}_{2}\left(\mathrm{CO}_{3}\right)_{3}\right]$. Acta Crystallogr. 2001, E37, 32-34. [CrossRef]

17. Douglass, $\mathrm{M}$. Tetrasodium uranyl tricarbonate, $\mathrm{Na}_{4} \mathrm{UO}_{2}\left(\mathrm{CO}_{3}\right)_{3}$. Anal. Chem. 1956, 28, 1635. [CrossRef]

18. Ondruš, P.; Skála, R.; Veselovský, F.; Sejkora, J.; Vitti, C. Čejkaite, the triclinic polymorph of $\mathrm{Na}_{4}\left(\mathrm{UO}_{2}\right)\left(\mathrm{CO}_{3}\right)_{3}-\mathrm{A}$ new mineral from Jachymov, Czech Republic. Am. Min. 2003, 88, 686-693. [CrossRef]

19. Mazzi, F.; Rinaldi, F. La struttura cristallina del $\mathrm{K}_{3} \mathrm{Na}\left(\mathrm{UO}_{2}\right)\left(\mathrm{CO}_{3}\right)_{3}$. Period. Mineral. 1961, 30, 1-21.

20. Kubatko, K.-A.; Helean, K.B.; Navrotsky, A.; Burns, P.C. Thermodynamics of uranyl minerals: Enthalpies of formation of rutherfordine, $\mathrm{UO}_{2} \mathrm{CO}_{3}$, andersonite, $\mathrm{Na}_{2} \mathrm{CaUO}_{2}\left(\mathrm{CO}_{3}\right)_{3}\left(\mathrm{H}_{2} \mathrm{O}\right)_{5}$, and grimselite, $\mathrm{K}_{3} \mathrm{NaUO}_{2}\left(\mathrm{CO}_{3}\right)_{3} \mathrm{H}_{2} \mathrm{O}$. Amer. Mineral. 2005, 90, 1284-1290. [CrossRef]

21. Walenta, K. Widenmannit und Joliotit, zwei neue Uranylkarbonatmineralien aus dem Schwarzwald. Schweiz. Mineral. Petrogr. Mitt. 1976, 56, 167-185. 
22. Li, Y.; Burns, P. The crystal structure of synthetic grimselite, $\mathrm{K}_{3} \mathrm{Na}\left[\left(\mathrm{UO}_{2}\right)\left(\mathrm{CO}_{3}\right)_{3}\right]\left(\mathrm{H}_{2} \mathrm{O}\right)$. Can. Mineral. 2001, 39, $1147-1151$. [CrossRef]

23. Plášil, J.; Fejfarová, K.; Skála, R.; Škoda, R.; Meisser, N.; Hloušek, J.; Císařová, I.; Dušek, M.; Veselovský, F.; Čejka, J.; et al. The crystal chemistry of the uranyl carbonate mineral grimselite, $(\mathrm{K}, \mathrm{Na})_{3} \mathrm{Na}\left[\left(\mathrm{UO}_{2}\right)\left(\mathrm{CO}_{3}\right)_{3}\right]\left(\mathrm{H}_{2} \mathrm{O}\right)$, from Jáchymov, Czech Republic. Mineral. Mag. 2012, 76, 443-453. [CrossRef]

24. Kubatko, K.A.; Burns, P.C. The Rb analogue of grimselite, $\mathrm{Rb}_{6} \mathrm{Na}_{2}\left(\left(\mathrm{UO}_{2}\right)\left(\mathrm{CO}_{3}\right)_{3}\right)_{2}\left(\mathrm{H}_{2} \mathrm{O}\right)$. Acta Crystallogr. Cryst. Struct. Commun . 2004, C60, 25-26. [CrossRef] [PubMed]

25. Skála, R.; Ondruš, P.; Veselovský, F.; Císařová, I.; Hloušek, J. Agricolaite, a new mineral of uranium from Jáchymov, Czech Republic. Mineral. Petrol. 2011, 103, 169-175. [CrossRef]

26. Anderson, A.; Chieh, C.; Irish, D.E.; Tong, J.P.K. An X-Ray crystallographic, Raman, and infrared spectral study of crystalline potassium uranyl carbonate, $\mathrm{K}_{4} \mathrm{UO}_{2}\left(\mathrm{CO}_{3}\right)_{3}$. Can. J. Chem. 1980, 58, 1651-1658. [CrossRef]

27. Han, J.-C.; Rong, S.-B.; Chen, Q.-M.; Wu, X.-R. The determination of the crystal structure of tetrapotassium uranyl tricarbonate by powder X-ray diffraction method. Chin. J. Chem. 1990, 4, 313-318.

28. Chernorukov, N.G.; Mikhailov, Y.N.; Knyazev, A.V.; Kanishcheva, A.S.; Zamkovaya, E.V. Synthesis and crystal structure of rubidium uranyltricarbonate. Russ. J. Coord. Chem. 2005, 31, 364-367. [CrossRef]

29. Charushnikova, I.A.; Fedoseev, A.M.; Perminov, V.P. Synthesis and Crystal Structure of Cesium Actinide(VI) Tricarbonate Complexes $\mathrm{Cs}_{4} \mathrm{AnO}_{2}\left(\mathrm{CO}_{3}\right)_{3} \cdot 6 \mathrm{H}_{2} \mathrm{O}, \mathrm{An}(\mathrm{VI})=\mathrm{U} ., \mathrm{Np}$, Pu. Radiochemistry 2016, 58, 578-585. [CrossRef]

30. Mereiter, K. Structure of cesium tricarbonatodioxouranate(VI) hexahydrate. Acta Crystallogr. Cryst. Struct. Commun. 1988, C44, 1175-1178. [CrossRef]

31. Krivovichev, S.V.; Burns, P.C. Synthesis and crystal structure of Cs4(UO2(CO3)3). Radiochemistry 2004, 46, 12-15. [CrossRef]

32. Serezhkin, V.N.; Soldatkina, M.A.; Boiko, N.V. Refinement of the crystal-structure of $\left(\mathrm{NH}_{4}\right)_{4} \mathrm{UO}_{2}\left(\mathrm{CO}_{3}\right)_{3}$. J. Struct. Chem. 1983, 24, 770-774. [CrossRef]

33. Mereiter, K. Structure of Thallium Tricarbonatodioxouranat (VI). Acta Crystallogr. Cryst. Struct. Commun. 1986, C42, 1682-1684. [CrossRef]

34. Axelrod, J.M.; Grimaldi, F.S.; Milton, C.; Murata, K.J. The uranium minerals from the Hillside mine, Yavapai County, Arizona. Am. Mineral. 1951, 36, 1-22.

35. Mayer, H.; Mereiter, K. Synthetic bayleyite, $\mathrm{Mg}_{2}\left[\mathrm{UO}_{2}\left(\mathrm{CO}_{3}\right)_{3}\right] \cdot 18 \mathrm{H}_{2} \mathrm{O}$ : Thermochemistry, crystallography and crystal structure. Tschermaks Mineral. Petrogr. Mitt. 1986, 35, 133-146. [CrossRef]

36. Mereiter, K. Synthetic swartzite, $\mathrm{CaMg}\left[\mathrm{UO}_{2}\left(\mathrm{CO}_{3}\right)_{3}\right] \cdot 12 \mathrm{H}_{2} \mathrm{O}$, and its strontium analogue, $\mathrm{SrMg}\left[\mathrm{UO}_{2}\left(\mathrm{CO}_{3}\right)_{3}\right] \cdot 12 \mathrm{H}_{2} \mathrm{O}: \mathrm{Crystallogra}^{-}$ phy and crystal structures. Neues Jahrb. Mineral. Mon. 1986, 1986, 481-492.

37. Amayri, S.; Arnold, T.; Foerstendorf, H.; Geipel, G.; Bernhard, G. Spectroscopic characterization of synthetic becquerelite, $\left.\mathrm{Ca}\left[\mathrm{UO}_{2}\right)_{6} \mathrm{O}_{4}(\mathrm{OH})_{6}\right] \cdot 8 \mathrm{H}_{2} \mathrm{O}$, and swartzite, $\mathrm{CaMg}\left[\mathrm{UO}_{2}\left(\mathrm{CO}_{3}\right)_{3}\right] \cdot 12 \mathrm{H}_{2} \mathrm{O}$. Can. Mineral. 2004, 42, 953-962. [CrossRef]

38. Vochten, R.; Van Haverbeke, L.; Van Springel, K. Synthesis of liebigite and andersonite, and study of their thermal behavior and luminescence. Can. Mineral. 1993, 31, 167-171.

39. Smith, J.L. Two new minerals—-medjidite (sulphate of uranium and lime)—Liebigite (carbonate of uranium and lime). Am. J. Sci. Arts 1848, 5, 336-338.

40. Mereiter, K. The crystal structure of liebigite, $\mathrm{Ca}_{2} \mathrm{UO}_{2}\left(\mathrm{CO}_{3}\right)_{3} \cdot \sim 11 \mathrm{H}_{2} \mathrm{O}$. Tschermaks Mineral. Petrogr. Mitt. 1982, 30, $277-288$. [CrossRef]

41. Kampf, A.R.; Plášil, J.; Kasatkin, A.V.; Marty, J.; Čejka, J. Markeyite, a new calcium uranyl carbonate mineral from the Markey mine, San Juan County, Utah, USA. Mineral. Mag. 2018, 82, 1089-1100. [CrossRef]

42. Kampf, A.R.; Olds, T.A.; Plášil, J.; Burns, P.C.; Marty, J. Natromarkeyite and pseudomarkeyite, two new calcium uranyl carbonate minerals from the Markey mine, San Juan County, Utah, USA. Mineral. Mag. 2020, 84, 753-765. [CrossRef]

43. Mereiter, K. Structure of strontium tricarbonatodioxouranate(VI) octahydrate. Acta Crystallogr. Cryst. Struct. Commun. 1986, C42, 1678-1681. [CrossRef]

44. Olds, T.; Sadergaski, L.; Plášil, J.; Kampf, A.; Burns, P.; Steele, I.; Marty, J.; Carlson, S.; Mills, O. Leószilárdite, the first Na,Mgcontaining uranyl carbonate from the Markey Mine, San Juan County, Utah, USA. Mineral. Mag. 2017, 81, 1039-1050. [CrossRef]

45. Gurzhiy, V.V.; Krzhizhanovskaya, M.G.; Izatulina, A.R.; Sigmon, G.E.; Krivovichev, S.V.; Burns, P.C. Structure refinement and thermal stability studies of the uranyl carbonate mineral Andersonite, $\mathrm{Na}_{2} \mathrm{Ca}\left[\left(\mathrm{UO}_{2}\right)\left(\mathrm{CO}_{3}\right)_{3}\right] \cdot(5+\mathrm{x}) \mathrm{H}_{2} \mathrm{O}$. Minerals 2018 , 8, 586 . [CrossRef]

46. Coda, A.; Della Giusta, A.; Tazzoli, V. The structure of synthetic andersonite, $\mathrm{Na}_{2} \mathrm{Ca}_{2}\left[\mathrm{UO}_{2}\left(\mathrm{CO}_{3}\right)_{3}\right] \cdot \mathrm{xH} \mathrm{H}_{2} \mathrm{O}(\mathrm{x}=5.6)$. Acta Cryst. 1981, B37, 1496-1500. [CrossRef]

47. Mereiter, K. Neue kristallographische Daten ueber das Uranmineral Andersonit. Anz. Österr. Akad. Wiss. Mathemat. Naturwiss. Kl. 1986, 123, 39-41.

48. Plášil, J.; Čejka, J. A note on the molecular water content in uranyl carbonate mineral andersonite. J. Geosci. 2015, 60, 181-187. [CrossRef]

49. Coda, A. Ricerche sulla struttura cristallina dell'Andersonite. Atti Accad. Naz. Lincei Rend. Cl. Sci. Fis. Mat. Nat. Ser. 1963, 34, 299-304.

50. Čejka, J.; Urbanec, Z.; Čejka, J., Jr. To the crystal chemistry of andersonite. Neu. Jb. Mineral. Mh. 1987, 11, 488-501. 
51. De Neufville, J.P.; Kasdan, A.; Chimenti, R.J.L. Selective detection of uranium by laser-induced fluorescence: A potential remote-sensing technique. 1: Optical characteristics of uranyl geologic targets. Appl. Opt. 1981, 20, 1279-1296. [CrossRef]

52. Amayri, S.; Arnold, T.; Reich, T.; Foerstendorf, H.; Geipel, G.; Bernhard, G.; Massanek, A. Spectroscopic characterization of the uranium carbonate andersonite $\mathrm{Na}_{2} \mathrm{Ca}\left[\mathrm{UO}_{2}\left(\mathrm{CO}_{3}\right)_{3}\right] \cdot 6 \mathrm{H}_{2} \mathrm{O}$. Environ. Sci. Technol. 2004, 38, 6032-6036. [CrossRef]

53. Frost, R.L.; Carmody, O.; Ertickson, K.L.; Weier, M.L.; Čejka, J. Molecular structure of the uranyl mineral andersonite-A Raman spectroscopic study. J. Molec. Struct. 2004, 703, 47-54. [CrossRef]

54. Čejka, J. To the chemistry of andersonite and thermal composition of dioxo-tricarbonatouranates. Coll. Czech. Chem. Commun. 1969, 34, 1635-1656. [CrossRef]

55. Čejka, J.; Urbanec, Z. Thermal and infrared spectrum analyses of natural and synthetic andersonites. J. Therm. Anal. 1988, 33, 389-394. [CrossRef]

56. Vochten, R.; van Haverbeke, L.; van Springel, K.; Blaton, N.; Peeters, M. The structure and physicochemical characteristics of a synthetic phase compositionally intermediate between liebigite and andersonite. Can. Mineral. 1994, 32, 553-561.

57. Plášil, J.; Mereiter, K.; Kampf, A.R.; Hloušek, J.; Škoda, R.; Čejka, J.; Němec, I.; Ederová, J. Braunerite IMA 2015-123. CNMNC Newsletter No. 31. Mineral. Mag. 2016, 80, 692.

58. Plášil, J.; Čejka, J.; Sejkora, J.; Hloušek, J.; Škoda, R.; Novák, M.; Dušek, M.; Císařová, I.; Němec, I.; Ederová, J. Línekite, $\mathrm{K}_{2} \mathrm{Ca}_{3}\left[\left(\mathrm{UO}_{2}\right)\left(\mathrm{CO}_{3}\right)_{3}\right]_{2} .8 \mathrm{H}_{2} \mathrm{O}$, a new uranyl carbonate mineral from Jáchymov, Czech Republic. J. Geosci. $2017,62,201-213$. [CrossRef]

59. Kubatko, K.-A.; Burns, P. The crystal structure of a novel uranyl tricarbonate, $\left.\mathrm{K}_{2} \mathrm{Ca}_{3}\left[\left(\mathrm{UO}_{2}\right)\left(\mathrm{CO}_{3}\right)_{3}\right)\right]_{2}\left(\mathrm{H}_{2} \mathrm{O}\right)_{6}$. Can. Mineral. 2004, 42, 997-1003. [CrossRef]

60. Effenberger, H.; Mereiter, K. Structure of a cubic sodium strontium magnesium tricarbonatodioxouranate(VI) hydrate. Acta Crystallogr. Cryst. Struct. Commun. 1988, C44, 1172-1175. [CrossRef]

61. Olds, T.; Plášil, J.; Kampf, A.; Dal Bo, F.; Burns, P. Paddlewheelite, a New Uranyl Carbonate from the Jáchymov District, Bohemia, Czech Republic. Minerals 2018, 8, 511. [CrossRef]

62. Plášil, J.; Hloušek, J.; Kasatkin, A.V.; Belakovskiy, D.I.; Čejka, J.; Chernyshov, D. Ježekite, $\mathrm{Na}_{8}\left[\left(\mathrm{UO}_{2}\right)\left(\mathrm{CO}_{3}\right)_{3}\right]\left(\mathrm{SO}_{4}\right)_{2} \cdot 3 \mathrm{H}_{2} \mathrm{O}$, a new uranyl mineral from Jáchymov, Czech Republic. J. Geosci. 2015, 60, 259-267. [CrossRef]

63. Schrauf, A. Schröckingerit, ein neues Mineral von Joachimsthal. Tschermaks Mineral. Petrogr. Mitt. 1873, 1, 137-138.

64. Jaffe, H.W.; Sherwood, A.M.; Peterson, M.J. New data on schroeckingerite. Am. Mineral. 1948, 33, 152-157.

65. Smith, D.K. An X-ray crystallographic study of schroeckingerite and its dehydration product. Am. Mineral. 1959, 44, 1020-1025.

66. Mereiter, K. Crystal structure and crystallographic properties of a schröckingerite from Joachimsthal. Tschermaks Mineral. Petrogr. Mitt. 1986, 35, 1-18. [CrossRef]

67. Mereiter, K. The crystal structure of albrechtschraufite, $\mathrm{MgCa}_{4} \mathrm{~F}_{2}\left[\left(\mathrm{UO}_{2}\right)\left(\mathrm{CO}_{3}\right)_{3}\right]_{2} \cdot 17 \mathrm{H}_{2} \mathrm{O}$. Acta Crystallogr. 1984, A40, 247. [CrossRef]

68. Mereiter, K. Description and crystal structure of albrechtschaufite, $\mathrm{MgCa}_{4} \mathrm{~F}_{2}\left[\mathrm{UO}_{2}\left(\mathrm{CO}_{3}\right)_{3}\right]_{2} \cdot 17-18 \mathrm{H}_{2} \mathrm{O}$. Mineral. Petrol. 2013, 107, 179-188. [CrossRef]

69. Li, Y.; Burns, P.C. New structural arrangements in three ca uranyl carbonate compounds with multiple anionic species. J. Solid State Chem. 2002, 166, 219-228. [CrossRef]

70. Plášil, J.; Škoda, R. Crystal structure of the (REE)-uranyl carbonate mineral shabaite-(Nd). J. Geosci. 2017, 62, 97-105. [CrossRef]

71. Deliens, M.; Piret, P. La shabaïte-(Nd), Ca(TR $)_{2}\left(\mathrm{UO}_{2}\right)\left(\mathrm{CO}_{3}\right)_{4}(\mathrm{OH})_{2} \cdot 6 \mathrm{H}_{2} 0$, nouvelle espéce minérale de Kamoto, Shaba, Zaïre. Eur. J. Mineral. 1989, 1, 85-88. [CrossRef]

72. Fedosseev, A.M.; Gogolev, A.V.; Charushnikova, I.A.; Shilov, V.P. Tricarbonate complex of hexavalent Am with guanidinium: Synthesis and structural characterization of $\left[\mathrm{C}\left(\mathrm{NH}_{2}\right)_{3}\right]_{4}\left[\mathrm{AmO}_{2}\left(\mathrm{CO}_{3}\right)_{3}\right] \cdot 2 \mathrm{H}_{2} \mathrm{O}$, comparison with $\left[\mathrm{C}\left(\mathrm{NH}_{2}\right)_{3}\right]_{4}\left[\mathrm{An} \mathrm{O}_{2}\left(\mathrm{CO}_{3}\right)_{3}\right](A n=\mathrm{U}$, Np, Pu). Radiochim. Acta 2011, 99, 679-686. [CrossRef]

73. Reed, W.A.; Oliver, A.G.; Rao, L. Tetrakis(tetramethylammonium) tricarbonatodioxidouranate octahydrate. Acta Crystallogr. 2011, 67, 301-303. [CrossRef]

74. Allen, P.G.; Bucher, J.J.; Clark, D.L.; Edelstein, N.M.; Ekberg, S.A.; Gohdes, J.W.; Hudson, E.A.; Kaltsoyannis, N.; Lukens, W.W.; Neu, M.P.; et al. Multinuclear NMR, Raman, EXAFS, and X ray diffraction studies of uranyl carbonate complexes in near-neutral aqueous solution. X-ray structure of (C(NH2)3)6((UO2)3(CO3)6)·6.5(H2O). Inorg. Chem. 1995, 34, 4797-4807.

75. Olds, T.; Plášil, J.; Kampf, A.; Simonetti, A.; Sadergaski, L.; Chen, Y.-S.; Burns, P. Ewingite: Earth's most complex mineral. Geology 2017, 45, 1007-1010. [CrossRef]

76. Guillemin, C.; Protas, J. Ianthinite et wyartite. Bull. Société Française Minéralogie Cristallogr. 1959, 82, 80-86. [CrossRef]

77. Burns, P.C.; Finch, R.J. Wyartite: Crystallographic evidence for the first pentavalent-uranium mineral. Am. Mineral. 1999, 84, 1456-1460. [CrossRef]

78. Frost, R.L.; Henry, D.A.; Erickson, K. Raman spectroscopic detection of wyartite in the presence of rabejacite. J. Raman Spectrosc. 2004, 35, 255-260. [CrossRef]

79. Hawthorne, F.C.; Finch, R.J.; Ewing, R.C. The crystal structure of dehydrated wyartite, $\mathrm{Ca}\left(\mathrm{CO}_{3}\right)\left[\mathrm{U}^{5+}\left(\mathrm{U}^{6+} \mathrm{O}_{2}\right)_{2} \mathrm{O}_{4}(\mathrm{OH})\right]\left(\mathrm{H}_{2} \mathrm{O}\right)_{3}$. Can. Mineral. 2006, 44, 1379-1385. [CrossRef]

80. Deliens, M.; Piret, P. La fontanite, carbonate hydraté d'uranyle et de calcium, nouvelle espèce minérale de Rabejac, Hérault, France. Eur. J. Mineral. 1992, 4, 1271-1274. [CrossRef] 
81. Hughes, K.A.; Burns, P.C. A new uranyl carbonate sheet in the crystal structure of fontanite, $\mathrm{Ca}\left[\left(\mathrm{UO}_{2}\right)_{3}\left(\mathrm{CO}_{3}\right)_{2} \mathrm{O}_{2}\right]\left(\mathrm{H}_{2} \mathrm{O}\right)_{6} \cdot A m$. Mineral. 2003, 88, 962-966. [CrossRef]

82. Cesbron, F.; Pierrot, R.; Verbeek, T. La roubaultite $\mathrm{Cu}_{2}\left(\mathrm{UO}_{2}\right)_{3}(\mathrm{OH})_{10} \cdot 5 \mathrm{H}_{2} \mathrm{O}$, une nouvelle espèce minérale. Bull. Société Française Minéralogie Cristallogr. 1970, 93, 550-554. [CrossRef]

83. Ginderow, D.; Cesbron, F. Structure de la roubaultite $\mathrm{Cu}_{2}\left(\mathrm{UO}_{2}\right)_{3}\left(\mathrm{CO}_{3}\right)_{2} \mathrm{O}_{2}(\mathrm{OH})_{2} \cdot 4 \mathrm{H}_{2} \mathrm{O}$. Acta Crystallogr. 1985, 41, $654-657$.

84. Marckwald, W. Ueber Uranerze aus Deutsch-Ostafrika. Zent. Mineral. Geol. Paläontologie 1906, 1906, 761-763.

85. Christ, C.L.; Clark, J.R.; Evans, H.T., Jr. Crystal structure of rutherfordine, $\mathrm{UO}_{2} \mathrm{CO}_{3}$. Science 1955, 121, 472-473. [CrossRef] [PubMed]

86. Frondel, C.; Meyrowitz, R. Studies of uranium minerals (XIX): Rutherfordine, diderichite, and clarkeite. Am. Mineral. 1956, 41, 127-133.

87. Finch, R.J.; Cooper, M.A.; Hawthorne, F.C.; Ewing, R.C. Refinement of the crystal structure of rutherfordine. Can. Mineral. 1999, 37, 929-938.

88. Plášil, J. A unique structure of uranyl-carbonate mineral sharpite: A derivative of the rutherfordine topology. Z. Krist. Cryst. Mater. 2018, 233, 579-586. [CrossRef]

89. Melón, M.J. La sharpite, nouveau carbonate d'uranyle du Congo belge. Bull. Séances l'Institut R. Colonial Belg. 1938, 9, 333-336.

90. Cejka, J.; Mrazek, Z.; Urbanec, Z. New data on sharpite, a calcium uranyl carbonate. Neues Jahrb. Mineral. Monatsh. 1984, 1984, 109-117.

91. Elton, N.J.; Hooper, J.J. Widenmannite from Cornwall, England: The second world occurrence. Mineral. Mag. 1995, 59, 745-749. [CrossRef]

92. Plášil, J.; Čejka, J.; Sejkora, J.; Škácha, P.; Goliáš, V.; Jarka, P.; Laufek, F.; Jehlička, J.; Němec, I.; Strnad, L. Widenmannite, a rare uranyl lead carbonate: Occurrence, formation and characterization. Miner. Mag. 2010, 74, 97-110. [CrossRef]

93. Plášil, J.; Palatinus, L.; Rohlíček, J.; Houdková, L.; Klementová, M.; Goliáš, V.; Škácha, P. Crystal structure of lead uranyl carbonate mineral widenmannite: Precession electron-diffraction and synchrotron powder-diffraction study. Am. Mineral. 2014, 99, 276-282. [CrossRef]

94. Deliens, M.; Piret, P. La kamototïte-(Y), un nouveau carbonate d'uranyle et de terres rares de Kamoto, Shaba, Zaïre. Bull. Minéralogie 1986, 109, 643-647. [CrossRef]

95. Plášil, J.; Petř́íček, V. Crystal structure of the (REE)-uranyl carbonate mineral kamotoite-(Y). Mineral. Mag. 2017, 81, 653-660. [CrossRef]

96. Deliens, M.; Piret, P. Bijvoetite et lepersonnite, carbonates hydrates d'uranyle et de terres rares de Shinkolobwe, Zaire. Can. Mineral. 1982, 22, 231-238.

97. Li, Y.; Burns, P.C.; Gault, R.A. A new rare-earth element uranyl carbonate sheet in the structure of bijvoetite-(Y). Can. Mineral. 2000, 38, 153-162. [CrossRef]

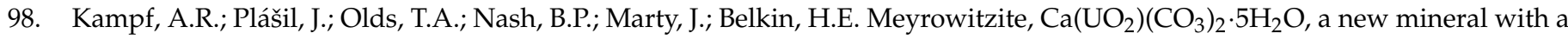
novel uranyl-carbonate sheet. Am. Mineral. 2019, 104, 603-610. [CrossRef]

99. Deliens, M.; Piret, P. L'astrocyanite-(Ce), $\mathrm{Cu}_{2}(\mathrm{TR})_{2}\left(\mathrm{UO}_{2}\right)\left(\mathrm{CO}_{3}\right)_{5}(\mathrm{OH})_{2} \cdot 1,5 \mathrm{H}_{2} \mathrm{O}$, nouvelle espèce minérale de Kamoto, Shaba, Zaïre. Eur. J. Mineral. 1990, 2, 407-411. [CrossRef]

100. Vochten, R.; Deliens, M. Blatonite, $\mathrm{UO}_{2} \mathrm{CO}_{3} \cdot \mathrm{H}_{2} \mathrm{O}$, A new uranyl carbonate monohydrate from San Juan County, Utah. Can. Mineral. 1998, 36, 1077-1081.

101. Coleman, R.G.; Ross, D.R.; Meyrowitz, R. Zellerite and metazellerite, new uranyl carbonates. Am. Mineral. 1966, 51, $1567-1578$.

102. Vochten, R.; Deliens, M.; Medenbach, O. Oswaldpeetersite, $\left(\mathrm{UO}_{2}\right)_{2} \mathrm{CO}_{3}(\mathrm{OH})_{2} \cdot 4 \mathrm{H}_{2} \mathrm{O}$, a new basic uranyl carbonate mineral from the Jomac uranium mine, San Juan County, Utah, U.S.A. Can. Mineral. 2001, 39, 1685-1689. [CrossRef]

103. Thompson, M.E.; Weeks, A.D.; Sherwood, A.M. Rabbittite, a new uranyl carbonate from Utah. Am. Mineral. 1955, 40, $201-206$.

104. Deliens, M.; Piret, P. L'urancalcarite, $\mathrm{Ca}\left(\mathrm{UO}_{2}\right)_{3} \mathrm{CO}_{3}(\mathrm{OH})_{6} \cdot 3 \mathrm{H}_{2} \mathrm{O}$, nouveau minéral de Shinkolobwe, Shaba, Zaïre. Bull. Minéralogie 1984, 107, 21-24. [CrossRef]

105. Vogl, J.F. Drei neue Mineral-Vorkommen von Joachimsthal. Jahrb. Kais. Königlichen Geol. Reichsanst. 1853, 4, $220-223$.

106. Piret, P.; Deliens, M. New crystal data for $\mathrm{Ca}, \mathrm{Cu}, \mathrm{UO}_{2}$ hydrated carbonate: Voglite. J. Appl. Crystallogr. 1979, 12, 616. [CrossRef]

107. Frost, R.L.; Dickfos, M.J.; Cejka, J. Raman spectroscopic study of the uranyl carbonate mineral zellerite. J. Raman Spectrosc. 2008, 39, 582-586. [CrossRef]

108. Chiappero, P.J.; Sarp, H. Nouvelles données sur la znucalite et seconde occurrence: Le Mas d'Alary, Lodève (Hérault, France). Arch. Sci. 1993, 46, 291-301.

109. Ondruš, P.; Veselovský, F.; Rybka, R. Znucalite, $\mathrm{Zn}_{12}\left(\mathrm{UO}_{2}\right) \mathrm{Ca}\left(\mathrm{CO}_{3}\right)_{3}(\mathrm{OH})_{22} \cdot 4 \mathrm{H}_{2} \mathrm{O}$, a new mineral from Príbram, Czechoslovakia. Neues Jahrb. Mineral. Mon. 1990, 1990, 393-400.

110. Hawthorne, F.C. Graphical enumeration of polyhedral clusters. Acta Crystallogr. 1983, A39, 724-736. [CrossRef]

111. Krivovichev, S.V. Combinatorial topology of salts of inorganic oxoacids: Zero-, one- and two-dimensional units with cornersharing between coordination polyhedra. Crystallogr. Rev. 2004, 10, 185-232. [CrossRef]

112. Krivovichev, S.V. Structural Crystallography of Inorganic Oxysalts; Oxford University Press: Oxford, UK, 2008 ; p. 303.

113. Burns, P.C.; Miller, M.L.; Ewing, R.C. $U^{6+}$ minerals and inorganic phases: A comparison and hierarchy of structures. Can. Mineral. 1996, 34, 845-880. 
114. Burns, P.C. $\mathrm{U}^{6+}$ minerals and inorganic compounds: Insights into an expanded structural hierarchy of crystal structures. Canad. Mineral. 2005, 43, 1839-1894. [CrossRef]

115. Krivovichev, S.V. Topological complexity of crystal structures: Quantitative approach. Acta Crystallogr. 2012, A68, 393-398. [CrossRef]

116. Krivovichev, S.V. Structural complexity of minerals: Information storage and processing in the mineral world. Mineral. Mag. 2013, 77, 275-326. [CrossRef]

117. Krivovichev, S.V. Which inorganic structures are the most complex? Angew. Chem. Int. Ed. 2014, 53, 654-661. [CrossRef]

118. Krivovichev, S.V. Structural complexity of minerals and mineral parageneses: Information and its evolution in the mineral world. In Highlights in Mineralogical Crystallography; Danisi, R., Armbruster, T., Eds.; Walter de Gruyter: Berlin, Germany, 2015; pp. 31-73.

119. Krivovichev, S.V. Structural complexity and configurational entropy of crystalline solids. Acta Crystallogr. 2016, B72, 274-276.

120. Gurzhiy, V.V.; Tyumentseva, O.S.; Izatulina, A.R.; Krivovichev, S.V.; Tananaev, I.G. Chemically Induced Polytypic Phase Transitions in the $\mathrm{Mg}\left[\left(\mathrm{UO}_{2}\right)\left(\mathrm{TO}_{4}\right)_{2}\left(\mathrm{H}_{2} \mathrm{O}\right)\right]\left(\mathrm{H}_{2} \mathrm{O}\right)_{4}(\mathrm{~T}=\mathrm{S}$, Se) System. Inorg. Chem. 2019, 58, 14760-14768. [CrossRef]

121. Gurzhiy, V.V.; Tyumentseva, O.S.; Belova, E.V.; Krivovichev, S.V. Chemically induced symmetry breaking in the crystal structure of guanidinium uranyl sulfate. Mendeleev Commun. 2019, 29, 408-410. [CrossRef]

122. Kornyakov, I.V.; Kalashnikova, S.A.; Gurzhiy, V.V.; Britvin, S.N.; Belova, E.V.; Krivovichev, S.V. Synthesis, characterization and morphotropic transitions in a family of $\mathrm{M}\left[\left(\mathrm{UO}_{2}\right)\left(\mathrm{CH}_{3} \mathrm{COO}\right)_{3}\right]\left(\mathrm{H}_{2} \mathrm{O}\right)_{\mathrm{n}}(M=\mathrm{Na}, \mathrm{K}, \mathrm{Rb}, \mathrm{Cs} ; \mathrm{n}=0-1.0)$ compounds. Z. Kristallogr. 2020, 235, 95-103. [CrossRef]

123. Kornyakov, I.V.; Tyumentseva, O.S.; Krivovichev, S.V.; Gurzhiy, V.V. Dimensional evolution in hydrated K+-bearing uranyl sulfates: From 2D-sheets to 3D frameworks. Cryst. Eng. Comm. 2020, 22, 4621-4629. [CrossRef]

124. Krivovichev, S.V. Ladders of information: What contributes to the structural complexity in inorganic crystals. Z. Kristallogr. 2018, 233, 155-161. [CrossRef]

125. Krivovichev, V.G.; Krivovichev, S.V.; Charykova, M.V. Selenium minerals: Structural and chemical diversity and Complexity. Minerals 2019, 9, 455. [CrossRef]

126. Tyumentseva, O.S.; Kornyakov, I.V.; Britvin, S.N.; Zolotarev, A.A.; Gurzhiy, V.V. Crystallographic insights into uranyl sulfate minerals formation: Synthesis and crystal structures of three novel cesium uranyl sulfates. Crystals 2019, 9, 660. [CrossRef]

127. Gurzhiy, V.V.; Kuporev, I.V.; Kovrugin, V.M.; Murashko, M.N.; Kasatkin, A.V.; Plášil, J. Crystal chemistry and structural complexity of natural and synthetic uranyl selenites. Crystals 2019, 9, 639. [CrossRef]

128. Langmuir, D. Uranium solution-mineral equilibria at low temperatures with applications to sedimentary ore deposits. Geochim. Cosmochim. Acta 1978, A42, 547-569. [CrossRef]

129. Gorman-Lewis, D.; Burns, P.; Fein, J. Review of uranyl mineral solubility measurements. J. Chem. Thermodyn. 2008, 40, 335-352. [CrossRef]

130. Walenta, V.K. Grimselit, ein neues Kalium-NatriumUranylkarbonat aus dem Grimselgebiet (Oberhasli, Kt. Bern, Schweiz). Schweiz. Mineral. Petrogr. Mitt. 1972, 52, 93-108.

131. Mereiter, K. Hemimorphy of crystals of liebigite. Naaes Jahrb. Mineral. Monatsh. 1986, 1986, 325-328.

132. Larsen, E.S. The probable identity of uranothallite and liebigite. Am. Mineral. 1917, 2, 87.

133. Krivovichev, S.V.; Burns, P.C. Actinide compounds containing hexavalent cations of the VI group elements (S, Se, Mo, Cr, W). In Structural Chemistry of Inorganic Actinide Compounds; Krivovichev, S.V., Burns, P.C., Tananaev, I.G., Eds.; Elsevier: Amsterdam, The Netherland, 2007; pp. 95-182.

134. Shuvalov, R.R.; Burns, P.C. A monoclinic polymorph of uranyl dinitrate trihydrate, $\left[\mathrm{UO}_{2}\left(\mathrm{NO}_{3}\right)_{2}\left(\mathrm{H}_{2} \mathrm{O}\right)_{2}\right] \cdot \mathrm{H}_{2} \mathrm{O}$. Acta Crystallogr. 2003, C59, 71-73.

135. Thuéry, P. Uranyl Ion Complexes with Cucurbit[ $n]$ urils $(n=6,7$, and 8): A new family of uranyl-organic frameworks. Cryst. Growth Des. 2008, 8, 4132-4143. [CrossRef]

136. Gurzhiy, V.V.; Kornyakov, I.V.; Tyumentseva, O.S. Uranyl nitrates: Byproducts of the synthetic experiments or key indicators of the reaction progress? Crystals 2020, 10, 1122. [CrossRef]

137. Demartin, F.; Diella, V.; Donzelli, S.; Gramaccioli, C.M.; Pilati, T. The importance of accurate crystal structure determination of uranium minerals. I. Phosphuranylite $\mathrm{KCa}\left(\mathrm{H}_{3} \mathrm{O}\right)_{3}\left(\mathrm{UO}_{2}\right)_{7}\left(\mathrm{PO}_{4}\right)_{4} \mathrm{O}_{4} \cdot 8 \mathrm{H}_{2} \mathrm{O}$. Acta Crystallogr. 1991, B47, 439-446. [CrossRef]

138. Kepler, J. Harmonices Mundi Libri V; Forni: Bologna, Italy, 1619.

139. Blatov, V.A.; Shevchenko, A.P.; Proserpio, D.M. Applied topological analysis of crystal structures with the program package ToposPro. Cryst. Growth. Des. 2014, 14, 3576-3586. [CrossRef] 